\title{
Diversidade e patrimônio cultural
}

\author{
Ana Maria Goulart Bustamante \\ Jorge Kleber Teixeira Silva \\ "A diversidade das culturas humanas está atrás de nós, \\ à nossa volta e à nossa frente" \\ (LÉVI-STRAUSS, 2000) \\ “[...] a diversidade cultural é, para o gênero humano, tão necessária \\ como a diversidade biológica para a natureza" \\ (Declaração Universal sobre a Diversidade Cultural)
}

Uma das chaves de entendimento da geografia do Brasil contemporâneo diz respeito ao tema das diversidades brasileiras e ao conjunto dos direitos a elas relacionados, de acordo com leis e instrumentos de governança internacionais, como a Convenção para a Proteção do Patrimônio Mundial, Cultural e Natural, instituída, em 1972, durante a Conferência Geral da Organização das Nações Unidas para a Educação, a Ciência e a Cultura - UNESCO, e a Convenção sobre Diversidade Biológica, estabelecida, em 1992, durante a Conferência das Nações Unidas sobre Meio Ambiente e Desenvolvimento, a Rio-92.

Com efeito, assim como existe uma diversidade sociocultural e natural no território brasileiro, forjada no decorrer do processo histórico de povoamento do País, existe igualmente uma complexidade normativa que regula, na atualidade, essa diversidade, por meio de uma variedade de fontes, como leis, decretos, tratados e convenções internacionais, que são absorvidos pela legislação nacional, conforme Quadro 1. 
Quadro 1 - Atos multilaterais promulgados pelo Brasil no campo da diversidade cultural

\begin{tabular}{|c|c|c|c|c|c|}
\hline \multirow[b]{2}{*}{ Nome } & \multicolumn{2}{|c|}{ Promulgação } & \multicolumn{2}{|c|}{$\begin{array}{c}\text { Aprovação pelo Congresso } \\
\text { Nacional }\end{array}$} & \multirow[b]{2}{*}{ Observações } \\
\hline & Decreto $\mathrm{n}$. & Data & $\begin{array}{l}\text { Decreto } \\
\text { Legislativo } \\
\mathrm{n} .\end{array}$ & Data & \\
\hline $\begin{array}{l}\text { Convenção Relativa à Proteção } \\
\text { do Patrimônio Mundial, } \\
\text { Cultural e Natural }\end{array}$ & 80978 & 12.12 .1977 & (1) 74 & 30.06 .1977 & $\begin{array}{l}\text { Adotada em Paris, } \\
\text { em novembro de 1972, } \\
\text { na XVII sessão da } \\
\text { Conferência Geral } \\
\text { da Organização das } \\
\text { Nações Unidas para } \\
\text { a Educação, a Ciência } \\
\text { e a Cultura (1) }\end{array}$ \\
\hline $\begin{array}{l}\text { Convenção sobre Diversidade } \\
\text { Biológica }\end{array}$ & 2519 & 16.03.1998 & (1) 2 & 03.02 .1994 & $\begin{array}{l}\text { Assinada no Rio de Janeiro em } \\
05.06 .1992(1)\end{array}$ \\
\hline $\begin{array}{l}\text { Convenção no } 169 \text { da } \\
\text { Organização Internacional do } \\
\text { Trabalho - OIT sobre Povos } \\
\text { Indígenas e Tribais }\end{array}$ & 5051 & 19.04 .2004 & (1)143 & 20.06 .2002 & $\begin{array}{l}\text { Adotada em Genebra, em } \\
27.06 .1989 \text { (1) }\end{array}$ \\
\hline $\begin{array}{l}\text { Convenção para a Salvaguarda } \\
\text { do Patrimônio Cultural } \\
\text { Imaterial }\end{array}$ & 5753 & 12.04 .2006 & (1) 22 & 01.02 .2006 & $\begin{array}{l}\text { Adotada em Paris, } \\
\text { em 17.10.2003 } \\
\text { e assinada em } \\
03.11 .2003(1)\end{array}$ \\
\hline $\begin{array}{l}\text { Convenção sobre a Proteção e } \\
\text { Promoção da Diversidade das } \\
\text { Expressões Culturais }\end{array}$ & 6177 & 01.08 .2007 & 485 & 20.12 .2006 & $\begin{array}{l}\text { Assinada em Paris, } \\
\text { em 20.10.2005, } \\
\text { com Instrumento } \\
\text { de Ratificação } \\
\text { depositado pelo } \\
\text { Brasil em 16.01.2007. } \\
\text { Entrou em vigor } \\
\text { internacional em } \\
\text { 18.03.2007 }\end{array}$ \\
\hline
\end{tabular}

Fonte: Shiraishi Neto, J. (Org.). Direito dos povos e das comunidades tradicionais no Brasil: declarações, convenções internacionais e dispositivos jurídicos definidores de uma política nacional. Manaus: Universidade Federal do Amazonas - UFAM, Programa de Pós-Graduação em Sociedade e Cultura na Amazônia - PPGSCA; Fundação Ford, 2007. (Coleção documentos de bolso, n. 1). Disponível em: <http://novacartografiasocial.com/?wpdmact=process\&did=MjEuaG90bGluaw==>. Acesso em: jan. 2016

Desde a Convenção para a Proteção do Patrimônio Mundial, Cultural e Natural, de 1972, a UNESCO divulga regularmente uma lista na qual são elencados bens considerados de importância para toda a humanidade. No Brasil, a distribuição espacial desses bens, escolhidos como patrimônio da humanidade (Mapa 1), reflete a geografia traçada pelos processos históricos que construíram a sociodiversidade cultural brasileira. Isto é, eles se localizam principalmente na costa atlântica leste, nos muitos portos "naturais" associados ao povoamento inicial da colônia portuguesa e que hoje são as cidades históricas, desde São Luís, no Maranhão, e Olinda, em Pernambuco, esta última ligada ao porto de Recife, além de São Cristóvão, em Sergipe, Salvador, na Bahia (ou Baía de Todos os Santos) e Rio de Janeiro, na Baía de Guanabara. O patrimônio mundial ainda avança para o interior de Minas Gerais e Goiás, seguindo os caminhos da mineração de ouro e diamantes, e para o Rio Grande do Sul, onde se encontram as ruínas das missões dos jesuítas, que tentaram criar outra forma de convívio com e entre indígenas. 
Mapa 1 - Patrimônio Mundial - 2013

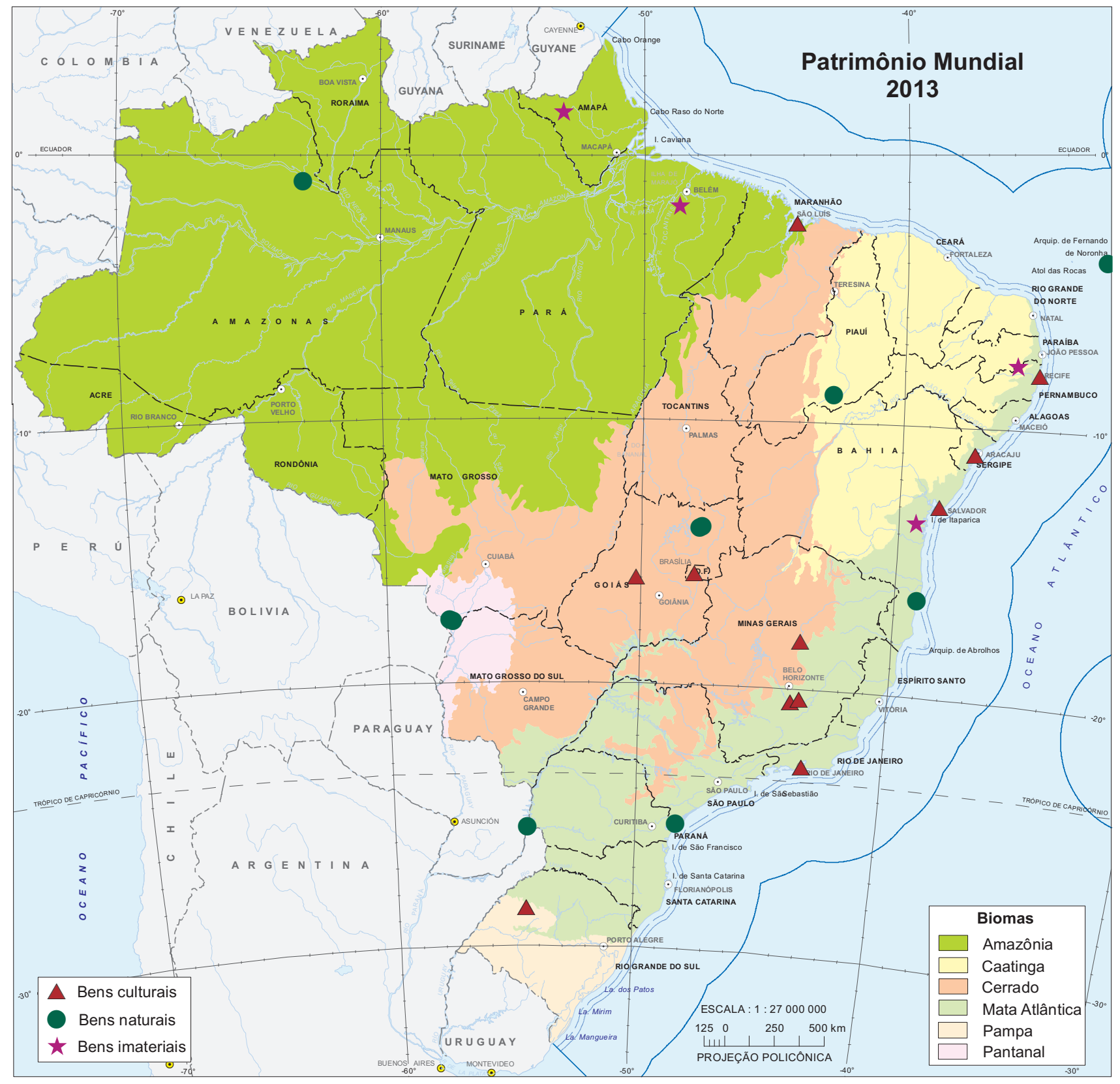

Fontes: 1. Lista do Patrimônio Mundial no Brasil. Brasília, DF: Organização das Nações Unidas para a Educação, a Ciência e a Cultura - Unesco, [2013]. Disponível em: <http://www.unesco.org/new/pt/brasilia/culture/world-heritage/list-of-world-heritage-in-brazil/\#c1048555>. Acesso: jan. 2016. 2. Indicadores de desenvolvimento sustentável: Brasil 2015. Rio de Janeiro: IBGE, 2015. Disponível em: <http://www.ibge.gov.br/home/geociencias/ recursosnaturais/ids/default_2015.shtm>. Acesso em: jan. 2016. 
Ainda de acordo com o Mapa 1, o patrimônio mundial natural do Brasil é também reconhecido e significativo, pois indica a apropriação da natureza e de sua biodiversidade, em razão de sua riqueza simbólica e cultural, ilustrada em bens como o Parque Nacional do Iguaçu, onde ficam as famosas Cataratas do Iguaçu, a Costa do Descobrimento, no litoral da Bahia, e as ilhas atlânticas, que abrangem o Parque Nacional de Fernando de Noronha e o Atol das Rocas. Outras áreas destacadas pelo patrimônio mundial representam os diferentes biomas do Brasil, como as áreas protegidas da Amazônia, da Mata Atlântica, do Pantanal e do Cerrado. O Bioma Caatinga está representado, no patrimônio mundial, pelo Parque Nacional da Serra da Capivara, que abriga grande riqueza arqueológica e natural.

A escolha dos bens do patrimônio mundial é feita por uma comissão formada por mais de 20 países, incumbida de avaliar as candidaturas propostas pelos órgãos de patrimônio dos países signatários da Convenção. No Brasil, o órgão responsável pelo Patrimônio Cultural Material e Imaterial é o Instituto do Patrimônio Histórico e Artístico Nacional - IPHAN, e as ações governamentais de preservação dos bens culturais são inscritas desde 1936 em quatro livros: Livro do Tombo Arqueológico, Etnográfico e Paisagístico; Livro do Tombo Histórico; Livro do Tombo das Belas Artes; e Livro do Tombo das Artes Aplicadas' ${ }^{1}$. Nosso objetivo, neste capítulo, é mostrar como esses bens são representativos do processo de ocupação do território brasileiro em sua rica diversidade sociocultural e natural.

\section{As diversidades coexistentes no Brasil}

Diversidade é uma palavra-chave na abordagem dos temas nacionais e, portanto, elemento central da geografia do Brasil. Além de abrigar 30\% de todas as florestas tropicais da Terra e seu maior sistema fluvial, o Brasil possui a mais vasta biota e reúne um número de espécies estimado em 1,8 milhão, incluindo-se entre os cinco países do mundo com maior diversidade biológica terrestre. A "megadiversidade"2 biológica brasileira distribuída num território de 8,5 milhões de quilômetros quadrados, se associa à imensa diversidade sociocultural captada em parte pelas informações demográficas oficiais (CENSO DEMOGRÁFICO 2010, 2011), que indicam um total de 190,8 milhões de pessoas residentes no Brasil, em 2010 (Tabela 1).

A diversidade sociocultural e natural resultante dessas interações está representada nos bens de valor histórico, artístico, arqueológico, etnográfico e paisagístico, além de bens que, embora tenham expressão material, são essencialmente imateriais, como saberes tradicionais, formas de expressão, celebrações e lugares especialmente ligados à identidade cultural e à continuidade das tradições.

\footnotetext{
1 Para informações mais detalhadas consultar o portal do IPHAN, no endereço: <http://portal.iphan.gov.br/pagina/detalhes/608>.

2 Para informações mais detalhadas, consultar: MEGADIVERSIDADE. Belo Horizonte: Conservação Internacional - CI Brasil, v. 1-5, 2005-2009. Disponível em: <http://www.conservation.org/global/brasil/publicacoes/Pages/revista-megadiversidade.aspx>. Acesso em: jan. 2016.
} 
Ao longo de um tempo que recua bem mais do que os quinhentos anos contados a partir do "descobrimento do Brasil", diversos povos contribuíram, e contribuem, para a composição da identidade cultural brasileira, marcando sua presença nas áreas mais remotas do Território Nacional. O levantamento e o mapeamento da riqueza cultural resultante das interações das populações do Brasil com os recursos naturais de seu território são formas de conhecimento da realidade brasileira e de construção de cidadania. Desse modo, é sob o ângulo da diversidade sociocultural e natural que se organiza este capítulo da geografia do Brasil. Mais especificamente, será enfatizada a forma como o Estado brasileiro vem absorvendo, em seu arcabouço legal como também em indicadores e cadastramentos, a diversidade presente em seu imenso território.

Tabela 1 - População residente, por sexo, segundo a cor ou raça - Brasil - 2010

\begin{tabular}{|c|c|c|c|c|c|c|}
\hline \multirow{3}{*}{ Cor ou raça } & \multicolumn{6}{|c|}{ População residente } \\
\hline & \multicolumn{3}{|c|}{ Total } & \multicolumn{3}{|c|}{ Percentual (\%) } \\
\hline & Total & Homens & Mulheres & Total & Homens & Mulheres \\
\hline Total & 190755799 & 93406990 & 97348809 & 100,0 & 49,0 & 51,0 \\
\hline Branca & 91051646 & 43652488 & 47399158 & 47,7 & 22,9 & 24,9 \\
\hline Preta & 14517961 & 7526611 & 6991350 & 7,6 & 4,0 & 3,7 \\
\hline Amarela & 2084288 & 951404 & 1132884 & 1,1 & 0,5 & 0,6 \\
\hline Parda & 82277333 & 40861864 & 41415469 & 43,1 & 21,4 & 21,7 \\
\hline Indígena & 817963 & 409907 & 408056 & 0,4 & 0,2 & 0,2 \\
\hline Sem declaração & 6608 & 4716 & 1892 & 0,0 & 0,0 & 0,0 \\
\hline
\end{tabular}

Fonte: Censo Demográfico 2010. Características da população e dos domicílios: resultados do universo. Rio de Janeiro: IBGE, 2011. Disponível em: <https://www.ibge.gov.br/home/estatistica/populacao/censo2010/caracteristicas_da_populacao/default_ caracteristicas_da_populacao.shtm >. Acesso em: jan. 2016.

Com efeito, da população residente no Brasil, em 2010 (Tabela 1), chama atenção a presença de cerca de 100 milhões de pessoas que se autodeclararam pardas ou pretas; de pouco mais de 2 milhões declaradas amarelas; de mais de 800 mil que se declararam indígenas; além de pouco mais de 91 milhões que se identificaram como brancas. Esse conjunto diversificado de pessoas, de acordo com suas variadas culturas, interage num território com seis biomas continentais predominantes - Amazônia, Mata Atlântica, Cerrado, Caatinga, Pantanal e Pampa, além dos biomas costeiros, cada um extremamente diverso em si mesmo, como será visto mais adiante.

Conforme mostram os Mapas 2, 3, 4 e 5, em todos os biomas convivem, em várias composições, populações que se autodeclararam segundo a diferente cor ou raça, o que dá uma dimensão das adaptações culturais que identificam a sociedade brasileira, espacialmente distribuída entre os diversos biomas continentais. A distribuição por cor ou raça autodeclarada reflete, de certo modo, o processo de povoamento do Brasil, que, por sua vez, está representado em seu patrimônio cultural. 
Mapa 2 - População, por cor ou raça - Parda - 2010

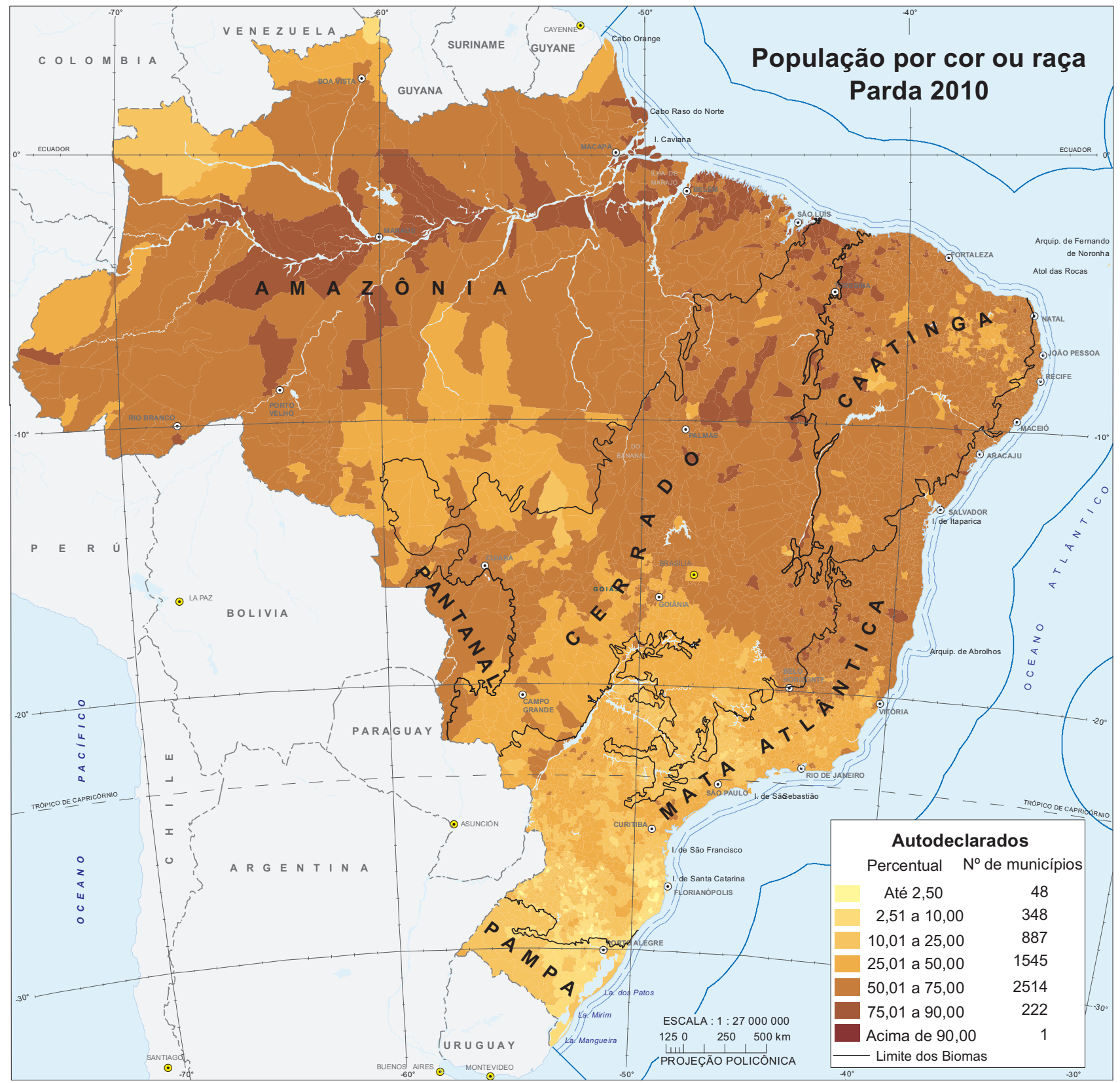

Fonte: Censo Demográfico 2010. Características da população e dos domicílios: resultados do universo. Rio de Janeiro: IBGE, 2011. Disponível em: <http:// www.ibge.gov.br/home/estatistica/populacao/censo2010/caracteristicas_da_populacao/default_caracteristicas_da_populacao.shtm>. Acesso em: jan. 2016. 
Mapa 3 - População, por cor ou raça - Branca - 2010

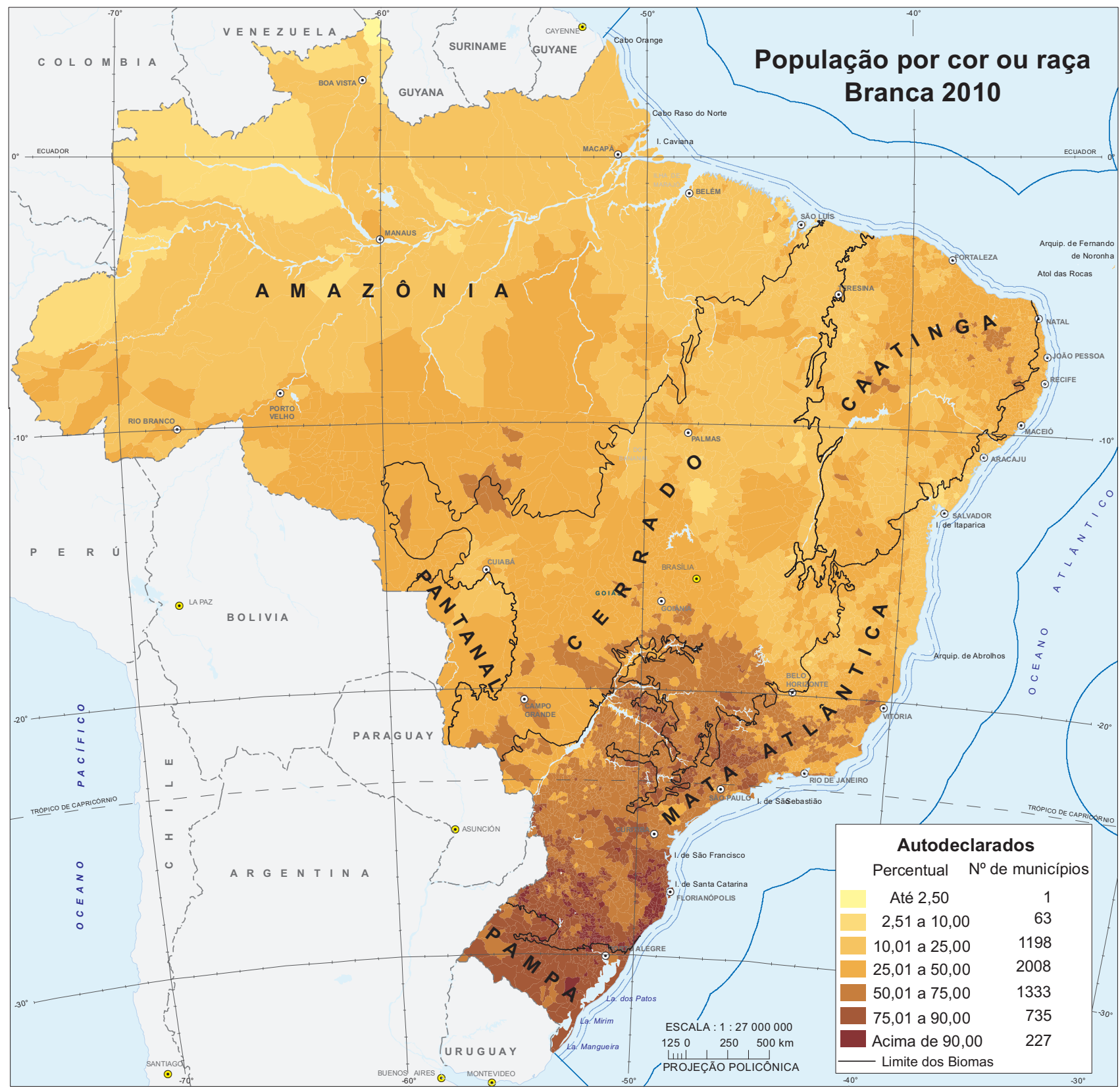

Fonte: Censo Demográfico 2010. Características da população e dos domicílios: resultados do universo. Rio de Janeiro: IBGE, 2011. Disponível em: <http:// www.ibge.gov.br/home/estatistica/populacao/censo2010/caracteristicas_da_populacao/default_caracteristicas_da_populacao.shtm>. Acesso em: jan. 2016. 
Mapa 4 - População, por cor ou raça - Preta - 2010

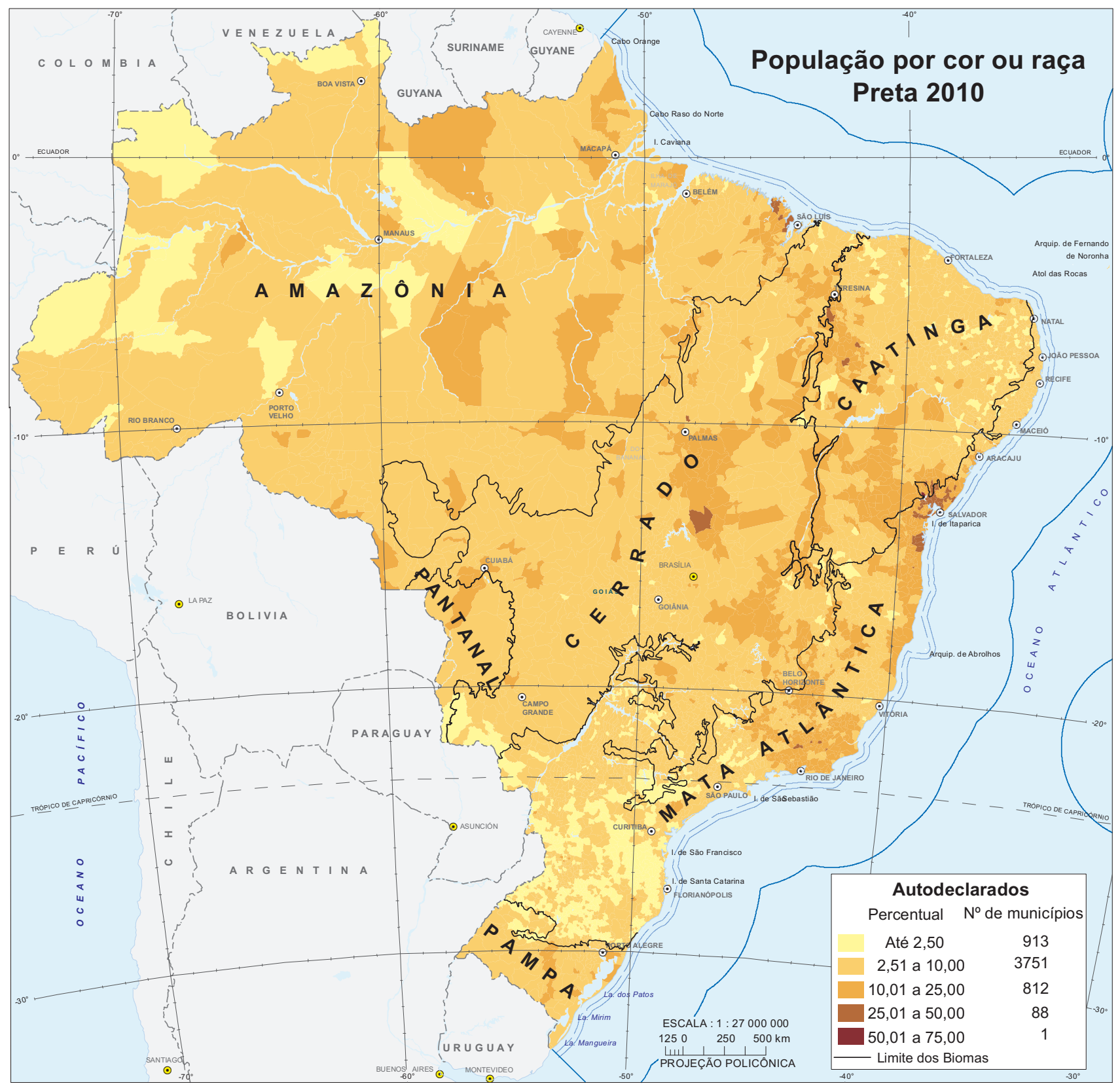

Fonte: Censo Demográfico 2010. Características da população e dos domicílios: resultados do universo. Rio de Janeiro: IBGE, 2011. Disponível em: <http:// www.ibge.gov.br/home/estatistica/populacao/censo2010/caracteristicas_da_populacao/default_caracteristicas_da_populacao.shtm>. Acesso em: jan. 2016. 
Mapa 5 - População, por cor ou raça - Indígena - 2010

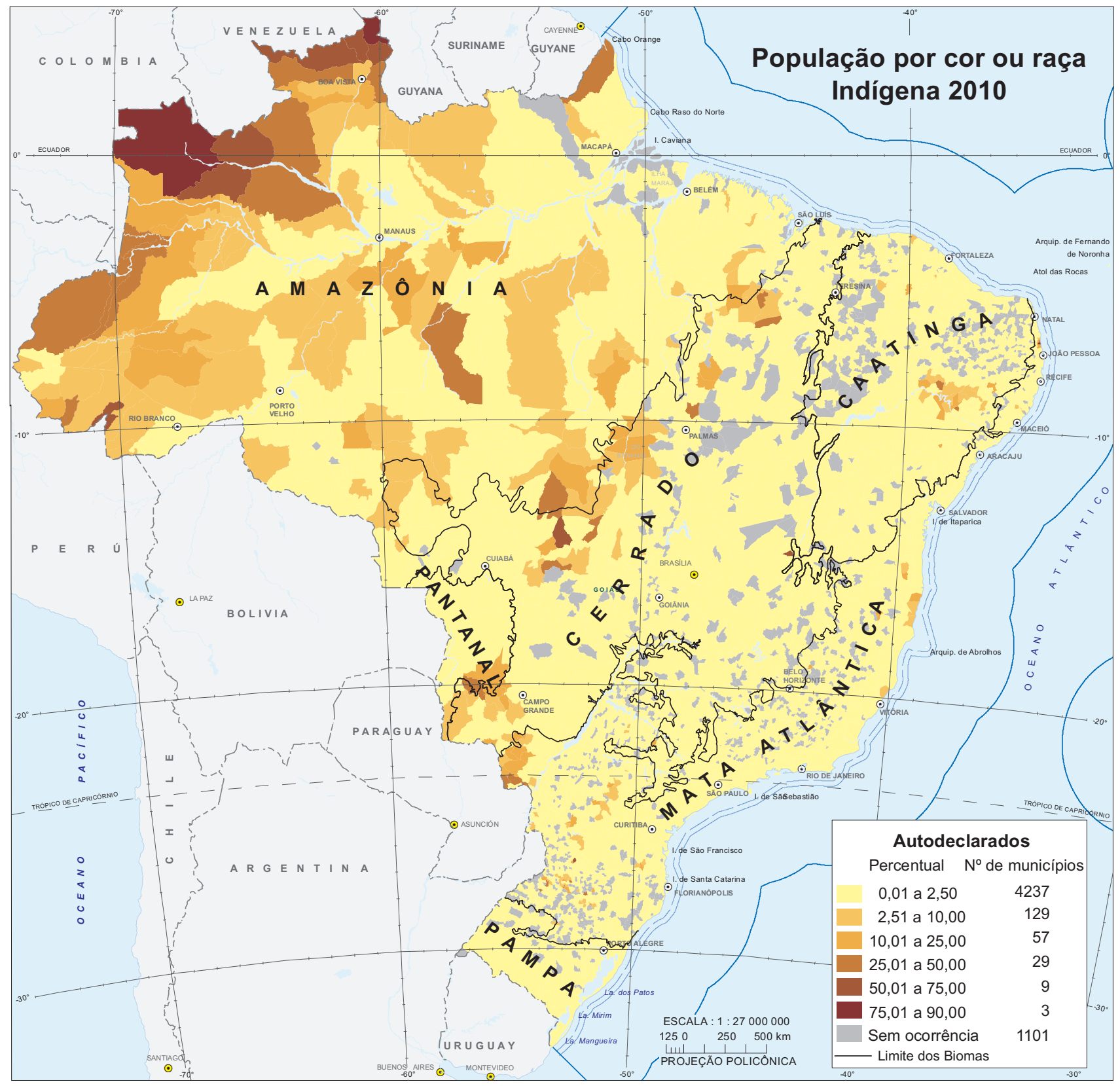

Fonte: Censo Demográfico 2010. Características da população e dos domicílios: resultados do universo. Rio de Janeiro: IBGE, 2011. Disponível em: <http:// www.ibge.gov.br/home/estatistica/populacao/censo2010/caracteristicas_da_populacao/default_caracteristicas_da_populacao.shtm>. Acesso em: jan. 2016. 
Em 2010, a população brasileira que se autodeclarava parda predominava na maior parte do Brasil, especialmente nos Biomas Amazônia, Cerrado, Caatinga e Pantanal, enquanto a população autodeclarada branca era dominante no Pampa e no sul da Mata Atlântica, e a proporção de pessoas que se autodeclararam pretas tem sua presença em todos os biomas, alcançando, em pontos dispersos do Território Nacional, uma proporção acima de $25 \%$ do total. A presença de diversas comunidades quilombolas, que vêm obtendo crescente reconhecimento legal quanto à posse de seus territórios, responde, por vezes, pelo percentual mais elevado da população autodeclarada preta na população municipal. ${ }^{3}$

A população autodeclarada indígena em 2010 se concentrava em municípios localizados no Bioma Amazônia, especialmente na porção ocidental, e, secundariamente, no Cerrado, onde se encontravam algumas concentrações significativas de autodeclarados indígenas, ainda esparsamente distribuídos em pequenos espaços dos outros biomas, com exceção do Bioma Pampa, onde é quase imperceptível a presença de autodeclarados indígenas.

Outra dimensão da diversidade sociocultural do Brasil se revela na sua diversidade linguística, que abriga o português como idioma predominante e línguas minoritárias, como o pomerano, falado por comunidades da Região Sul e do interior do Estado do Espírito Santo (ROCHE, 1968), além de mais de 200 troncos e famílias linguísticas indígenas faladas no domicílio por $37 \%$ das pessoas indígenas com 5 anos ou mais de idade (CENSO DEMOGRÁFICO 2010, 2011).

Tabela 2 - Pessoas indígenas de 5 anos ou mais de idade, segundo a condição de falar língua indígena no domicílio - Brasil - 2010

\begin{tabular}{|c|c|c|}
\hline \multirow{2}{*}{$\begin{array}{l}\text { Condição de falar } \\
\text { íngua indígena no domicílio }\end{array}$} & \multicolumn{2}{|c|}{ Pessoas indígenas de 5 anos ou mais de idade } \\
\hline & Total & Percentual $(\%)$ \\
\hline Total & 786674 & 100,0 \\
\hline Falavam & 293853 & 37,4 \\
\hline Não falavam & 449345 & 57,1 \\
\hline Sem declaração & 43476 & 5,5 \\
\hline
\end{tabular}

Fonte: Censo Demográfico 2010. Características da população e dos domicílios: resultados do universo. Rio de Janeiro: IBGE, 2011. Disponível em: <https://www.ibge.gov.br/home/estatistica/populacao/censo2010/caracteristicas_da_populacao/default_ caracteristicas_da_populacao.shtm >. Acesso em: jan. 2016.

Nota: Adaptada da Tabela 1.7 - Pessoas indígenas de 5 anos ou mais de idade, por sexo, condição de falar português no domicílio e localização do domicílio, segundo os grupos de idade e a condição de falar língua indígena no domicílio - Brasil - 2010. Disponível em: <https://biblioteca.ibge.gov.br/visualizacao/periodicos/95/cd_2010_indigenas_universo.pdf>. Acesso em: jan. 2016 .

3 O Decreto n. 4.887, de 20.11.2003, regulamentou o procedimento para identificação, reconhecimento, delimitação, demarcação e titulação das terras ocupadas por remanescentes das comunidades dos quilombos. O seu Art. $2 \stackrel{0}{ }$ considera "remanescentes das comunidades dos quilombos [...] os grupos étnico-raciais, segundo critérios de auto-atribuição, com trajetória histórica própria, dotados de relações territoriais específicas, com presunção de ancestralidade negra relacionada com a resistência à opressão histórica sofrida". 
É raramente lembrado que o uso das línguas indígenas foi proibido nos domínios portugueses da América, no fim do Século XVIII, e mesmo a diversidade linguística expressa nos nomes de lugares foi afetada quando o governo promoveu, na atual Região Norte, a substituição sistemática dos nomes geográficos de origem indígena por nomes transplantados da toponímia portuguesa. A política de Portugal foi menos eficiente em outras partes do Brasil, onde, na época, havia mais falantes da língua geral, difundida pelos missionários jesuítas (FREIRE, 2004). Os nomes geográficos da região onde o tupi predominou emprestam identidade a serras, rios, lugares que não tiveram o nome alterado e ainda hoje formam uma rica amostra do uso da língua geral na descrição de elementos naturais pelas populações, especialmente na atual Região Sudeste, onde era predominante (SAMPAIO, 1914).

\section{Diversidade natural e ocupação do território brasileiro}

Longe da visão determinista das relações entre população e recursos naturais, a abordagem aqui proposta relaciona biomas e diversidade sociocultural, e chama a atenção para uma das feições estruturantes da geografia brasileira, que é a rica diversidade coexistente em seu território e em sua sociedade. Para a formulação de políticas públicas que contemplam a diversidade biológica e a diversidade cultural, tendo em vista os parâmetros do desenvolvimento sustentável, o Mapa de biomas do Brasil ${ }^{4}$ (MAPA..., 2004a) tem sido um valioso instrumento, pois mostra a diversidade de áreas naturais e sua distribuição pelo território brasileiro, aí incluídos os limites político-administrativos de suas Unidades da Federação (Mapa 6). Conceituado como um conjunto de vida (vegetal e animal) constituído pelo agrupamento de tipos de vegetação contíguos e identificáveis em escala regional, o bioma apresenta condições geoclimáticas similares e história compartilhada de mudanças, o que resulta em uma diversidade biológica própria que, de diversas maneiras, condicionou e/ou influenciou o processo histórico de povoamento do Brasil e de seus estados.

\footnotetext{
4 O Mapa de biomas do Brasil, fruto da cooperação entre o IBGE e o Ministério do Meio Ambiente, baseia-se no Mapa de vegetação do Brasil (MAPA..., 2004b), utiliza um marco conceitual para mapeamento dos limites entre os biomas que foi objeto de ampla discussão em seminários que reuniram, além de técnicos e representantes regionais do IBGE, usuários potenciais tanto do governo quanto da comunidade científica e de organizações da sociedade civil atuantes no campo socioambiental. Um exemplo de utilização da abordagem por biomas na aplicação de leis federais é a exigência de reserva legal de vegetação em propriedades rurais que, a depender do bioma e do tipo de vegetação predominante, varia de $20 \%$ a $80 \%$ da área total do imóvel.
} 
Mapa 6 - Biomas - 2004

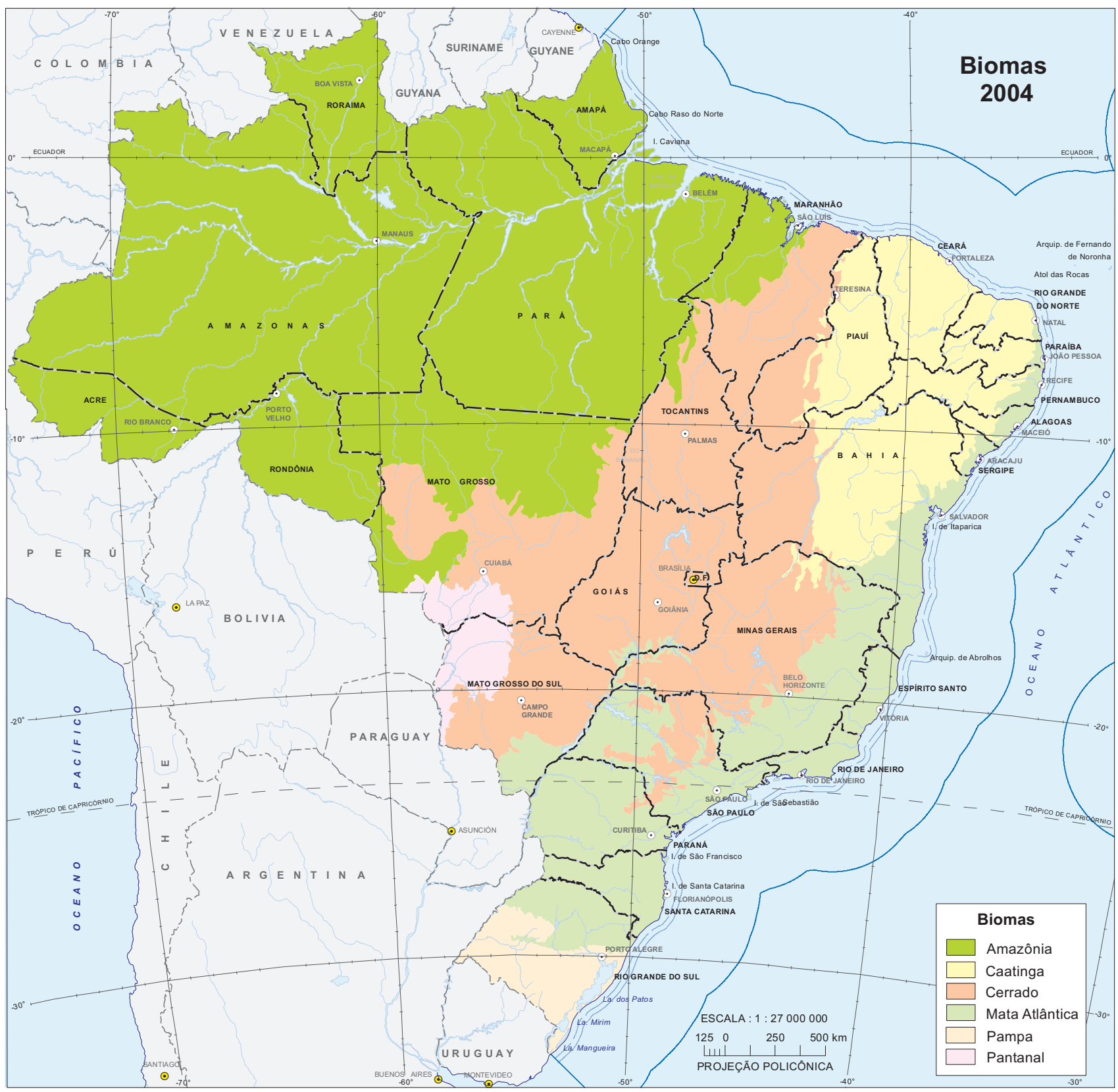

Fonte: Mapa de biomas do Brasil. Rio de Janeiro: IBGE, 2004. Disponível em: <ftp://ftp.ibge.gov.br/Cartas_e_Mapas/Mapas_Murais/>. Acesso em: jan. 2016. 
Os biomas foram designados a partir dos nomes mais usuais, em geral associados ao tipo de vegetação predominante e ao relevo. A área antropizada também é destacada na Tabela 3, pois a atividade humana no território, a depender dos recursos naturais e da densidade demográfica, pode resultar em grande impacto sobre o patrimônio ambiental, uma vez que a dinâmica da sociedade destaca elementos da paisagem e de seus atributos naturais e lhes dá uso e sentido, mas ao mesmo tempo pode alterá-la de modo mais ou menos reversível.

Tabela 3 - Biomas do Brasil, por área e por área antropizada - 2004

\begin{tabular}{|c|c|c|c|}
\hline Bioma & $\begin{array}{l}\text { Área aproximada } \\
\quad\left(\mathrm{em} \mathrm{km}{ }^{2}\right)(1)\end{array}$ & $\begin{array}{c}\text { Área } \\
(\%)\end{array}$ & $\begin{array}{l}\text { Área antropizada } \\
\text { (\% por Bioma) (2) }\end{array}$ \\
\hline Brasil (3) & 8514877 & 100,0 & 37,6 \\
\hline Amazônia & 4196943 & 49,3 & 16,0 \\
\hline Cerrado & 2036448 & 23,9 & 57,2 \\
\hline Mata Atlântica & 1110182 & 13,0 & 86,9 \\
\hline Caatinga & 176496 & 9,9 & 38,9 \\
\hline Pantanal & 150355 & 1,8 & 9,4 \\
\hline Pampa & 6608 & 2,1 & 33,2 \\
\hline
\end{tabular}

Fonte: Mapa de biomas do Brasil. Rio de Janeiro: IBGE, 2004. Disponível em: <ftp://ftp.ibge.gov.br/Cartas_e_Mapas/Mapas_ Murais/>. Acesso em: jan. 2016

(1) Datas médias de referência: Regiões Norte e Centro-Oeste - 2000; Regiões Nordeste e Sul - 1996; Região Sudeste - 1982. (2) Área total do Brasil de acordo com a Resolução n. 5, de 10.10.2002, da Presidência do IBGE, segundo quadro territorial vigente em 01.01.2001.

De acordo com a Tabela 4, em números relativos, o Bioma Amazônia ocupa a totalidade de cinco Unidades da Federação (Acre, Amapá, Amazonas, Pará e Roraima), grande parte de Rondônia (99\%), mais da metade de Mato Grosso (54\%), além de parte de Maranhão (34\%) e Tocantins (9\%). Esse bioma é definido pela unidade de clima, fisionomia florestal e localização geográfica. Ao abrigar a maior reserva de diversidade biológica do mundo, ele é também o maior bioma brasileiro em extensão e ocupa quase metade do Território Nacional (49\%). Cerca de $16 \%$ da área do Bioma Amazônia já se encontra alterada por atividades humanas.

Com 13\% da área do território brasileiro, o Bioma Mata Atlântica se distribui por toda a faixa continental atlântica leste do País. Ele se estende ainda em direção ao interior, nas Regiões Sudeste e Sul, e é definido tanto pela vegetação florestal predominante quanto pelo relevo diversificado. É o bioma continental mais alterado pela presença humana, com mais de $86 \%$ de sua área antropizada. Em termos de sua presença no mapa político do Brasil, ele ocupa inteiramente três estados, Espírito Santo, Rio de Janeiro e Santa Catarina, e 98\% do Paraná, além de porções de outras 11 Unidades da Federação.

Segundo bioma do Brasil em extensão (ocupa quase 24\% do território brasileiro), o Bioma Cerrado deve seu nome à vegetação predominante e se estende desde o litoral maranhense até a Região Centro-Oeste. Com mais de $57 \%$ de sua área antropizada, o Bioma Cerrado ocupa a totalidade do Distrito Federal, mais da metade dos Estados de Goiás (97\%), Maranhão (65\%), Mato Grosso do Sul (61\%), Minas Gerais (57\%) e Tocantins (91\%), além de porções de outros seis estados. 
Tabela 4 - Percentual aproximado de área ocupada por bioma, segundo as Unidades da Federação

\begin{tabular}{|c|c|c|c|c|c|c|}
\hline \multirow{2}{*}{ Unidades da Federação } & \multicolumn{6}{|c|}{ Percentual aproximado de área ocupada por bioma (\%) } \\
\hline & Amazônia & $\begin{array}{c}\text { Mata } \\
\text { Atlântica }\end{array}$ & Caatinga & Cerrado & Pantanal & Pampa \\
\hline Acre & 100,0 & & & & & \\
\hline Alagoas & & 52,0 & 48,0 & & & \\
\hline Amapá & 100,0 & & & & & \\
\hline Amazonas & 100,0 & & & & & \\
\hline Bahia & & 19,0 & 54,0 & 27,0 & & \\
\hline Ceará & & & 100,0 & & & \\
\hline Distrito Federal & & & & 100,0 & & \\
\hline Espírito Santo & & 100,0 & & & & \\
\hline Goiás & & 3,0 & & 97,0 & & \\
\hline Maranhão & 34,0 & & 100,0 & 65,0 & & \\
\hline Mato Grosso & 54,0 & & & 39,0 & 7,0 & \\
\hline Mato Grosso do Sul & & 14,0 & & 61,0 & 25,0 & \\
\hline Minas Gerais & & 41,0 & 2,0 & 57,0 & & \\
\hline Pará & 100,0 & & & & & \\
\hline Paraíba & & 8,0 & 92,0 & & & \\
\hline Paraná & & 98,0 & & 2,0 & & \\
\hline Pernambuco & & 17,0 & 83,0 & & & \\
\hline Piauí & & 63,0 & 37,0 & & & \\
\hline Rio de Janeiro & & 100,0 & & & & \\
\hline Rio Grande do Norte & & 5,0 & 95,0 & & & \\
\hline Rio Grande do Sul & & 37,0 & & & & 63,0 \\
\hline Rondônia & 99,0 & & & 0,2 & & \\
\hline Roraima & 100,0 & & & & & \\
\hline Santa Catarina & & 100,0 & & & & \\
\hline São Paulo & & 68,0 & & 32,0 & & \\
\hline Sergipe & & 51,0 & 49,0 & & & \\
\hline Tocantins & 9,0 & & & 91,0 & & \\
\hline Em questão $\mathrm{PI} \times \mathrm{CE}$ & & & 100,0 & & & \\
\hline
\end{tabular}

Fonte: Mapa de biomas do Brasil. Rio de Janeiro: IBGE, 2004. 1 mapa, color. Escala 1: 5.000.000; proj. policônica. Disponível em: <ftp://ftp.ibge.gov.br/Cartas_e_Mapas/Mapas_Murais/>. Acesso em: jan. 2016.

O Bioma Caatinga, típico da região de predomínio do clima semiárido do sertão nordestino, tem quase $40 \%$ de sua área antropizada e ocupa menos de $10 \%$ do território brasileiro. Ele se estende pela totalidade do Ceará (100\%) e mais de metade da Bahia (54\%), da Paraíba (92\%), de Pernambuco (83\%), do Piauí (63\%), do Rio Grande do Norte (95\%), quase metade de Alagoas (48\%) e de Sergipe (49\%), além de pequenas porções de Minas Gerais ( $2 \%$ ) e do Maranhão ( $1 \%)$.

O bioma de menor extensão no Brasil - mas que constitui a maior superfície inundável interiorana do mundo - é o Pantanal, que está presente em dois estados brasileiros (ocupa $25 \%$ de Mato Grosso do Sul e 7\% de Mato Grosso), enquanto o Bioma Pampa, que se define por um conjunto de vegetação de campo em relevo de planície, está restrito ao Rio Grande do Sul e ocupa $63 \%$ do território do estado. A área antropizada do Bioma Pampa chega a $33 \%$, enquanto o Bioma Pantanal é o que apresenta o menor percentual de alteração pelas atividades humanas $(9 \%)$. 
Especialistas como Oliveira (2004) destacam que os biomas podem ser muito diversos internamente em termos de vegetação e, se as florestas predominam na Amazônia e na Mata Atlântica, também estão presentes em menor proporção nos demais biomas do Brasil. No Cerrado e no Pantanal, a vegetação predominante é a savana, enquanto na Caatinga predomina a savana-estépica e, no Pampa, a estepe. A Mata Atlântica é o bioma com maior diversidade de tipos de vegetação, e o Bioma Amazônia é o único no Brasil onde se encontra o tipo de vegetação conhecido como campinarana, concentrado principalmente nas margens do Rio Negro.

\section{Diversidade cultural: povos e comunidades tradicionais e legislação}

Um quadro natural tão diverso oferece condições para o desenvolvimento de outros tipos de diversidade resultantes da interação dos habitantes com o meio, havendo mesmo populações tradicionais que se definem pelo próprio pertencimento ao bioma, como ocorre com os pantaneiros, os caatingueiros (Quadro 2); e outras, com seus recursos naturais, como os vazanteiros e piaçaveiros. A inclusão de dados relativos às populações tradicionais no quadro de diversidade social do Brasil se impõe desde 2007, quando o Decreto n. 6.040, de 07.02.2007, da Presidência da República, instituiu a Política Nacional de Desenvolvimento Sustentável dos Povos e Comunidades Tradicionais. Vale a pena destacar a formulação, por meio do referido Decreto, de três componentes para essa Política:

I - Povos e Comunidades Tradicionais: grupos culturalmente diferenciados e que se reconhecem como tais, que possuem formas próprias de organização social, que ocupam e usam territórios e recursos naturais como condição para sua reprodução cultural, social, religiosa, ancestral e econômica, utilizando conhecimentos, inovações e práticas gerados e transmitidos pela tradição;

II - Territórios Tradicionais: os espaços necessários à reprodução cultural, social e econômica dos povos e comunidades tradicionais, sejam eles utilizados de forma permanente ou temporária, observado, no que diz respeito aos povos indígenas e quilombolas, respectivamente, o que dispõem os arts. 231 da Constituição e 68 do Ato das Disposições Constitucionais Transitórias e demais regulamentações; e

III - Desenvolvimento Sustentável: o uso equilibrado dos recursos naturais, voltado para a melhoria da qualidade de vida da presente geração, garantindo as mesmas possibilidades para as gerações futuras (BRASIL, 2007).

Povos e Comunidades Tradicionais é um tema de seguidos decretos federais, que aos poucos promovem sua inclusão e sedimentam conceitos necessários para orientar as políticas públicas a serem criadas. Inicialmente, as comunidades tradicionais estavam no centro de uma política nacional de desenvolvimento sustentável, tema do Decreto de 27.12.2004, revogado pouco depois, com a edição do Decreto de 13.07.2006, sobre a Comissão Nacional de Desenvolvimento Sustentável dos Povos e Comunidades Tradicionais. Essa Comissão foi criada para coordenar a implementação da Política Nacional de Desenvolvimento Sustentável dos Povos e Comunidades Tradicionais, explicitada no Anexo do Decreto n. 6.040, de 2007. 
Quadro 2 - Populações tradicionais segundo direitos socioambiental e territorial associados

\begin{tabular}{|c|c|c|}
\hline $\begin{array}{l}\text { Povos e comunidades tradicionais citados } \\
\text { na composição da Comissão Nacional } \\
\text { de Desenvolvimento Sustentável } \\
\text { dos Povos e Comunidades Tradicionais }\end{array}$ & $\begin{array}{l}\text { Direito socioambiental } \\
\text { (Decreto n. 6.040/2007) }\end{array}$ & $\begin{array}{l}\text { Direito territorial } \\
\text { (Constituição Federal } \\
\text { do Brasil, de 1988) }\end{array}$ \\
\hline Povos indígenas & $x$ & $x$ \\
\hline Comunidades remanescentes de quilombos & $x$ & $x$ \\
\hline Ciganos & $x$ & - \\
\hline Comunidades de Terreiro & $x$ & - \\
\hline Pescadores artesanais & $x$ & - \\
\hline Caiçaras & $x$ & - \\
\hline Seringueiros & $x$ & - \\
\hline Agroextrativistas da Amazônia & $x$ & - \\
\hline Quebradeiras de coco-de-babaçu & $x$ & - \\
\hline Comunidades de fundo de pasto & $x$ & - \\
\hline Retireiros do Araguaia & $x$ & - \\
\hline Geraizeiros & $x$ & - \\
\hline Faxinais (ou faxinalenses) & $x$ & - \\
\hline Pomeranos & $x$ & - \\
\hline Pantaneiros & $\mathrm{x}$ & - \\
\hline
\end{tabular}

Fontes: 1. Brasil. Constituição (1988). Constituição da República Federativa do Brasil. Brasília, DF, [2009]. Disponível em: <http://www.presidencia.gov.br/legislacao> Acesso em: jan. 2016. 2. Brasil. Decreto n. 6.040, de 07.02.2007. Institui a Política Nacional de Desenvolvimento Sustentável dos Povos e Comunidades Tradicionais. Diário Oficial da União, Brasília, DF, ano 144, n. 28, 8 fev. 2007. Seção 1, p. 316-317. Disponível em: <http://www.presidencia.gov.br/legislacao>. Acesso em: jan. 2016.

Nota: Outra fonte, o Sistema Nacional de Informações e Indicadores Culturais, do IPHAN, inclui ainda outros povos, além dos citados, entre os quais: agricultores tradicionais, irmandades de negros, ribeirinhos, jangadeiros, campeiros, caatingueiros, açorianos, marisqueiras e caranguejeiras.

Incluídos no conceito de Povos e Comunidades Tradicionais, os povos e comunidades indígenas e quilombolas gozam de direitos especificados na Constituição Federal do Brasil de 1988 e em outras leis. Está definido constitucionalmente e pelas legislações infraconstitucionais que as populações tradicionais indígenas e quilombolas detêm o direito territorial. A Fundação Nacional do Índio - FunAı define legalmente as terras indígenas, e o Instituto Nacional de Colonização e Reforma Agrária - INCRA, as terras quilombolas. É importante compreender que há uma diferença conceitual e jurídica no tocante aos direitos socioambiental e territorial. O Decreto n. 6.040, de 07.02.2007, atribui aos povos e comunidades apenas direitos do primeiro tipo, o socioambiental, mas indica a existência do direito territorial para os povos indígenas e quilombolas. 


\section{Caminhos legais da conservação e populações tradicionais}

O socioambientalismo é um conceito surgido no Brasil, sem paralelo no ambientalismo internacional, que preconiza a integração de políticas setoriais, suas perspectivas e atores, num projeto de Brasil com um perfil próximo da realidade nacional; por isso, afirma a sustentabilidade e a busca de integração com os direitos humanos. Esse conceito, que vem sendo construído no Brasil desde a década de 1980, a partir de articulações políticas entre os movimentos sociais e ambientalista, identifica-se com o processo histórico de redemocratização do País, iniciado com o fim do regime militar, em 1984. Consagrado a partir da promulgação da nova Constituição Federal do Brasil, de 1988, o socioambientalismo trouxe contribuição também para legislações estaduais, em artigos referentes ao meio ambiente e à preservação cultural.

Em termos conceituais, o socioambientalismo se baseia na ideia de que as políticas públicas ambientais devem incluir e envolver as comunidades locais detentoras de conhecimentos e de práticas de manejo dos recursos naturais. Seu desenvolvimento se apoia na concepção de que, num país com tantas desigualdades sociais, um novo paradigma de desenvolvimento deve promover não só a sustentabilidade estritamente ambiental, ou seja, a sustentabilidade de espécies, ecossistemas e processos ecológicos, como também a sustentabilidade social, visando a uma gestão democrática do Território Nacional, portanto, em sintonia com as diversas culturas do País. Assim como prevê a Constituição Federal de 1988, o socioambientalismo vincula cultura e meio ambiente, ao promover a articulação das dimensões social, cultural, econômica, política e ambiental. Como noção jurídica, o socioambientalismo constitui uma construção derivada de interesses difusos que têm foco nos bens socioambientais.

Na década de 1990 e no início do Século XXI, o pensamento ambientalista avançou, no Brasil, numa direção voltada para a integração da sustentabilidade dos ecossistemas com a sobrevivência digna das populações neles instaladas historicamente. Os novos conceitos deram lastro para a criação, no Sistema Nacional de Unidades de Conservação - SNUC, instituído por meio da Lei n. 9.985, de 18.07.2000, de duas classes principais: as Unidades de Proteção Integral, que são para manutenção dos ecossistemas livres de alterações causadas por interferência humana, admitido apenas o uso indireto dos seus atributos naturais; e as Unidades de Uso Sustentável, em que a presença de populações humanas se alia à conservação da biodiversidade.

Os Parques Nacionais são um exemplo da categoria de proteção integral, cujo principal objetivo é a proteção da natureza, na qual é permitido apenas o uso indireto dos recursos naturais, para fins de recreação em contato com a natureza, pesquisa científica, turismo ecológico, educação ambiental e atividades similares que não envolvam consumo, coleta ou dano aos recursos naturais. As Unidades de Conservação de Uso Sustentável, alternativamente, são áreas que visam conciliar a conservação da natureza com o uso sustentável dos recursos naturais, desde que seja feito de forma a assegurar a perenidade dos recursos ambientais renováveis e dos processos ecológicos. Um exemplo são as Reservas Extrativistas da Amazônia, nas quais é permitida a atividade de seringueiros, e as Reservas Extrativistas 
Marinhas, onde pescadores e outros povos tradicionais podem extrair recursos naturais dentro de certos limites. Outras categorias de manejo desse Sistema Nacional, mesmo sem o objetivo explícito de proteger formas culturalmente diferenciadas de utilização dos recursos naturais, também abrigam experiências de manejo comunitário.

Com o SNUC, algo novo veio se conjugar com a visão preservacionista inicial, que por longo tempo orientou a criação de áreas protegidas, inspirada no conceito de "natureza intocada", do modelo adotado pelos Estados Unidos da América, sem considerar a realidade socioeconômica local e regional ou os povos e comunidades tradicionais instalados na área. O objetivo mais importante desse Sistema Nacional passou a ser a conservação da diversidade biológica, para a qual muitas vezes as comunidades tradicionais contribuem, com seu modo de vida e sua filosofia de utilização dos recursos naturais. Este é um dos motivos pelos quais os objetivos do SNUC, listados pelo Ministério do Meio Ambiente, responsável por sua gestão, incluem não apenas valorizar econômica e socialmente a diversidade biológica, mas proteger os recursos naturais necessários à subsistência de populações tradicionais, respeitando e valorizando seu conhecimento e sua cultura, além de promovê-las social e economicamente.

Tendo em vista a inclusão das famílias e grupos populacionais tradicionais, o Ministério do Desenvolvimento Social e Combate à Fome criou um manual de orientação para a inscrição no Cadastro Único para Programas Sociais do Governo Federal (Cadastro Único), o qual considera duas possibilidades de identificação, nele detalhadas. Em virtude de sua origem étnica, uma das classes do Cadastro permite identificar famílias que se autodeclararem como indígenas, quilombolas, ciganas e pertencentes a comunidades de terreiro. Em função de sua relação com o meio ambiente, identificam-se as famílias extrativistas, de pescadores artesanais e ribeirinhas. No meio rural, encontram-se os agricultores familiares. As informações sobre pertencimento a determinado grupo são autodeclaratórias, ou seja, a pessoa que se assume como responsável pela unidade familiar simplesmente identifica se a família pertence a determinado grupo. Quando possuem identificação própria, os grupos podem apresentar documentos, utilizados para dar mais qualidade às informações coletadas.

Povos tradicionais são, em geral, grandes conhecedores de possíveis fragilidades e potenciais de renovação dos recursos e, consequentemente, das técnicas de manejo e preservação dos ambientes em que se encontram. Em muitos casos, a identidade de comunidades extrativistas, que muito comumente vivem próximo ao local de ocorrência das espécies que mais utilizam, se atrela ao tipo de material coletado. Exemplos encontrados no Guia de cadastramento de grupos populacionais tradicionais e específicos (BRASIL, 2012), são andirobeiras, castanheiros, seringueiros, quebradeiras de coco-de-babaçu, apanhadores de flores sempre-vivas, catadoras de mangaba, cipozeiros, piaçaveiros, grupos que interagem com seus respectivos biomas e com eles são profundamente identificados em razão de sua atividade e principal meio de subsistência.

O surgimento das Reservas Extrativistas, no fim da década de 1980, respondeu à demanda dos seringueiros da Amazônia, em especial do Estado do Acre, de regularização fundiária das áreas de uso sustentável das populações tradicionais, onde se encontram os recursos florestais indispensáveis à sua sobrevivência, e depois passou a atender também 
outras populações. Diferentemente das Unidades de Proteção Integral, as Unidades de Uso Sustentável, entre as quais se encontram as Reservas Extrativistas, admitem a utilização direta do solo, incluindo o assentamento humano e as atividades agrícolas e extrativistas. A exploração dos recursos desta última unidade ocorre por meio de contrato de concessão de direito real de uso, tendo em vista que são áreas de domínio público, onde, no entanto, são vedadas as atividades econômicas incompatíveis com a preservação dos recursos naturais.

Nas Unidades de Conservação de Uso Sustentável, em especial as Reservas Extrativistas RESEX, Reservas de Desenvolvimento Sustentável - RDS e Florestas Nacionais - Flonas, todas elas áreas destinadas pelo Estado à proteção da biodiversidade, as populações tradicionalmente extrativistas têm garantido, por força de lei, o exercício das suas atividades, mas com o compromisso de conservação dos recursos florestais e de toda a biodiversidade relacionados com essas áreas. Tais condições também são observadas nos projetos de assentamento ambientalmente diferenciados, entre os quais se incluem os projetos de assentamento agroextrativista e os projetos de assentamento florestal, desenvolvidos no âmbito dos projetos de assentamento, sob a responsabilidade do INCRA. É grande a diversidade de populações tradicionais e de caminhos para a sua inclusão.

Povos tradicionais da Amazônia, os seringueiros são trabalhadores que extraem a resina da seringueira (Hevea brasiliensis), utilizada como matéria-prima na fabricação da borracha. Vivem, principalmente, nos Estados do Acre e do Amazonas. Os castanheiros coletam o fruto da castanheira-do-pará (Bertholletia excelsa), encontrada em toda a Região Amazônica, incluindo Rondônia, Acre, Amazonas, Pará, norte de Goiás e Mato Grosso. As andirobeiras extraem o óleo da semente da andiroba, historicamente utilizado como combustível e na fabricação de velas e sabonetes. A andiroba (Carapa guianensis Aublet), cujo óleo é aproveitado nas indústrias cosmética e farmacêutica, se encontra em praticamente todos os estados do Bioma Amazônia, especialmente nas várzeas e faixas alagáveis ao longo dos cursos d'água. Ainda na Amazônia, situados principalmente na região norte do Estado do Amazonas, os piaçabeiros são trabalhadores que extraem e comercializam a fibra da palmeira piaçava (Attalea funifera), em estado bruto ou beneficiado. Há registro também da exploração da piaçava no sul e no sudeste da Bahia.

Presentes, principalmente, nos Estados do Pará, do Maranhão, do Piauí e do Tocantins, em área dos Biomas Amazônia e Cerrado, as quebradeiras de coco-de-babaçu são trabalhadoras rurais que atuam na coleta e beneficiamento do coco da palmeira babaçu (Orbignya speciosa) e comercializam produtos como azeite, sabão, farinha e artesanato gerados a partir dessa coleta. Já as catadoras de mangaba comercializam, em feiras regionais, o fruto da mangabeira, que pode ser beneficiado e consumido na forma de polpas, doces e sorvetes. A mangabeira (Harconia speciosa) é encontrada no Cerrado e nas áreas de restinga, principalmente na Região Nordeste e na região Central do Brasil.

Entre as populações tradicionais do Cerrado, incluem-se ainda povos indígenas e também povos pretos ou pardos que ficaram por longo tempo em relativo isolamento e tiveram de adaptar seus modos de vida aos recursos naturais ali disponíveis. Assim, o Cerrado abriga quilombolas, geraizeiros, vazanteiros, sertanejos, ribeirinhos, que aprenderam, ao longo de séculos, a encontrar naquele bioma recursos para alimentação, utensílios e artesanato. 
É da região da Serra do Espinhaço, no Estado de Minas Gerais, o principal registro de ocorrência de apanhadores de sempre-vivas. As flores sempre-vivas são espécies de plantas herbáceas utilizadas na confecção de arranjos e outros enfeites. Os cipozeiros são grupos que extraem diferentes espécies de cipós e vendem em estado bruto ou utilizam na confecção de artesanato de cestas e balaios, chapéus, luminárias e outros objetos. Na Mata Atlântica, destaca-se a presença de diversas comunidades de cipozeiros nos Estados do Paraná e Santa Catarina. Na Amazônia, os cipozeiros se concentram na região norte do Estado do Amazonas.

Pescadores artesanais têm como principal atividade econômica a pesca artesanal, realizada por meio de conhecimento tradicional, repassado entre familiares, e da utilização sustentável dos recursos pesqueiros animais ou vegetais. Podem trabalhar desembarcados ou utilizar embarcação de pequeno porte, trabalhar com espécies diversas e utilizar várias técnicas. A pesca artesanal pode ser desenvolvida tanto no mar quanto nos rios e demais ambientes, como lagos, lagoas, açudes, represas, baías, enseadas, lagunas, estuários, manguezais etc. A categoria pescadores artesanais inclui caiçaras, marisqueiras e pantaneiros. Caiçaras são populações que vivem na zona litorânea, com maior representatividade nas Regiões Sul e Sudeste do Brasil. As marisqueiras são grupos de mulheres que assim se identificam e realizam, de forma artesanal, a coleta de mariscos (moluscos e crustáceos) em manguezais e bancos de areia. Os pantaneiros são os habitantes tradicionais do Bioma Pantanal.

Os pescadores artesanais ilustram bem a força econômica da produção das populações tradicionais, responsáveis por 60\% da pesca nacional em 2012, segundo o Ministério da Pesca de Aquicultura ${ }^{5}$. Mais de um milhão de pescadores sustentam suas famílias com o trabalho na captura dos peixes e frutos do mar, no beneficiamento e na comercialização do pescado. Desde 2004, esse Ministério emite o Registro Geral da Pesca, documento para caracterizar o pescador profissional e the prover acesso a programas sociais, como linhas de microcrédito e o Seguro-Defeso. O Seguro-Defeso é uma forma de seguro-desemprego, concedido pelo extinto Ministério do Trabalho e Emprego ${ }^{6}$ no período de paralisação temporária da pesca ou coleta de recursos pesqueiros, determinado pelos governos, visando à preservação das espécies.

Com distribuição geográfica semelhante à dos pescadores, os ribeirinhos são comunidades tradicionais agroextrativistas que vivem em regiões de várzea próximas de rio, cujo modo de organização, reprodução social, cultural e econômica se fundamenta na constante interação com o meio onde vivem, determinada pelo regime de cheias e vazantes e pelos recursos que o rio oferece. Nas regiões de planície e de baixa altitude no Pantanal e na Amazônia, áreas extensas são alagadas nos períodos chuvosos e provocam uma série de

\footnotetext{
5 Extinto a partir da Medida Provisória n. 696, de 02.10.2015. Suas competências foram transferidas para o Ministério da Agricultura, Pecuária e Abastecimento.

6 Foi extinto em 2015 após a criação do Ministério do Trabalho e Previdência Social, mediante a fusão do Ministério do Trabalho e Emprego com o Ministério da Previdência Social, oficializada por meio da Medida Provisória n. 696, de 02.10.2015.
} 
mudanças no modo de vida das populações. Nos períodos em que o rio diminui de volume, formam-se lagos que são importantes para a atividade de pesca. O terreno que foi alagado torna-se fértil na seca e propício ao plantio não só de espécies cultivadas em outras épocas, mas também abóbora, melancia e abacaxi. Algumas comunidades preservam formas de trabalho coletivo, como o mutirão, em que há o uso compartilhado da terra, ou a troca de serviços entre diferentes proprietários.

Outra população considerada tradicional, os agricultores familiares caracterizam-se pela forma como organizam a produção de alimentos, na qual os próprios componentes conduzem o processo produtivo. Apresentam características específicas de acordo com a região do País e o bioma natural onde se localizam, perpassando outras categorias de populações tradicionais, e, desse modo, mais do que um segmento econômico, representam um modo de vida ligado à realidade do local onde se encontram. Têm em comum a relação com o campo, por meio da atividade agrícola, na qual utilizam os recursos naturais da propriedade e a força de trabalho da família. Em geral, combinam a produção de várias culturas com a criação de animais e o beneficiamento de produtos, tanto para consumo da família quanto para comercialização. Para atender à demanda do Ministério do Desenvolvimento Agrário, o Censo Agropecuário 2006, do IBGE, adotou o conceito de "agricultura familiar", conforme a Lei n. 11.326, de 24.07.2006. Essa categoria vem chamando a atenção recentemente por se ligar à defesa das sementes crioulas e à proteção da agrobiodiversidade.

Mais um grupo para o qual se dirigem políticas públicas especiais, as comunidades de terreiro, de matriz africana, possuem uma cultura diferenciada e uma organização social própria, as quais constituem patrimônio cultural afro-brasileiro. As tradições de matriz africana são oriundas do continente africano, trazidas pelas pessoas traficadas para o Brasil que pertenciam a diversos grupos étnicos: Bantu, das regiões onde atualmente se localizam Moçambique, Angola e Congo; lorubá (denominados Nagôs ou Ketus); e Fon, do ocidente africano (Sudão, Nigéria e Benin). O terreiro congrega comunidades que possuem características comuns, tais como a manutenção das tradições de matriz africana, o respeito aos ancestrais, os valores de generosidade e solidariedade, o conceito amplo de família e uma relação próxima com o meio ambiente, além da oralidade, ou seja, o repasse de conhecimentos e da história dos povos pelo relato oral. Há uma grande diversidade de tradições de matriz africana no Brasil, como o Candomblé (com diferentes tipos), a Umbanda, o Batuque, o Tambor de Mina, a Quimbanda, a Jurema, entre outras. 
Quadro 3 - Manifestações religiosas afrobrasileiras e afroindígenas reportadas na Pesquisa Socioeconômica e Cultural de Povos e Comunidades Tradicionais de Terreiros, segundo as Regiões Metropolitanas

\begin{tabular}{|l|l|r|}
\hline Região Metropolitana & \multicolumn{1}{|c|}{ Denominação } & Casas praticantes \\
\hline \multirow{5}{*}{ Belém } & Umbanda & 533 \\
& Tambor de Mina & 523 \\
& Pena e Maracá & 402 \\
& Candomblé & 190 \\
& Nagô & 61 \\
& Mina de caboclo & 42 \\
& Pajeança & 10 \\
\hline \multirow{2}{*}{ Belo Horizonte } & Umbanda & 212 \\
& Candomblé & 163 \\
& Omolocô & 28 \\
\hline \multirow{2}{*}{ Porto Alegre } & Umbanda & 1003 \\
& Batuque & 830 \\
& Quimbanda & 777 \\
& Linha Cruzada & 72 \\
& Nagô & 32 \\
& Candomblé & 29 \\
\hline \multirow{2}{*}{ Recife } & Jurema & 896 \\
& Candomblé & 703 \\
& Umbanda & 365 \\
& Nagô & 181 \\
& Xangô & 10 \\
\hline
\end{tabular}

Fonte: Pesquisa Socioeconômica e Cultural de Povos e Comunidades Tradicionais de Terreiros: síntese de resultados. In: Alimento: direito sagrado. Pesquisa Socioeconômica e Cultural de Povos e Comunidades Tradicionais de Terreiros. Brasília, DF: Ministério do Desenvolvimento Social e Combate à Fome, 2011.p. 138. Disponível em: <http://www.ideiasnamesa.unb.br/upload/ bibliotecaldeias/04112015130257ok_Alimento_Direito_Sagrado_web.pdf>. Acesso em: jan. 2016.

\section{Leiłuras de avaliação da diversidade brasileira: Indicadores de Desenvolvimento Sustentável}

Os Indicadores de Desenvolvimento Sustentável - IDS - Brasil, de 2012 (Tabela 5), em sua dimensão ambiental, mostram que, no Brasil, nos anos recentes, houve forte crescimento tanto do número quanto da área das Unidades de Conservação federais, especialmente daquelas de uso sustentável, cujo número e proporção já superavam os das Unidades de Proteção Integral (173 e 139, respectivamente). Essa evolução representa o crescente reconhecimento pelo Estado das populações tradicionais como aliadas naturais e não obstáculo à conservação ambiental, tendo em vista que sua presença detém a degradação dos ambientes e dos recursos naturais.

Entre os biomas brasileiros, a Amazônia reúne a maior área protegida e a maior quantidade de Unidades de Conservação, com 14\% de sua área total em unidades federais, distribuída igualmente entre Unidades de Proteção Integral e Unidades de Uso Sustentável, ainda que as últimas totalizem um número superior ao dobro das primeiras. A Amazônia 
também contém as maiores Unidades de Conservação em extensão, dado que reflete a ocupação humana menos densa observada nesse bioma. Pode-se mesmo dizer que o tamanho e o número dessas unidades, na Amazônia, distorce a interpretação do conjunto da realidade brasileira, pois, na maior parte dos biomas, a área protegida é relativamente pequena e fragmentada, inferior a $4 \%$ e, portanto, bem abaixo da média mundial, de 5\%. Excluindo-se o Bioma Amazônia, que eleva a média de área protegida do Brasil para 8,8\%, e a área total protegida para mais de 750000 quilômetros quadrados $(\mathrm{km} 2)$, os demais biomas continentais juntos detêm pouco mais de $150000 \mathrm{~km} 2$ de área protegida, dos quais a maior parte em uso sustentável.

Tabela 5 - Quantidade, área e participação relativa no bioma, das Unidades de Conservação federais, por tipo de uso - Brasil - 2012

\begin{tabular}{|c|c|c|c|c|c|c|c|c|c|}
\hline \multirow{2}{*}{ Bioma } & \multicolumn{3}{|c|}{$\begin{array}{l}\text { Número de Unidades } \\
\text { de Conservação federais } \\
\text { (unidades) }\end{array}$} & \multicolumn{3}{|c|}{$\begin{array}{c}\text { Área das Unidades } \\
\text { de Conservação federais } \\
\left(\mathrm{km}^{2}\right)\end{array}$} & \multicolumn{3}{|c|}{$\begin{array}{c}\text { Participação relativa } \\
\text { da área das Unidades } \\
\text { de Conservação federais } \\
\text { na área do bioma (\%) }\end{array}$} \\
\hline & Total & $\begin{array}{l}\text { Prote- } \\
\text { ção } \\
\text { integral }\end{array}$ & $\begin{array}{l}\text { Uso } \\
\text { susten- } \\
\text { tável }\end{array}$ & Total & $\begin{array}{l}\text { Prote- } \\
\text { ção } \\
\text { integral }\end{array}$ & $\begin{array}{l}\text { Uso } \\
\text { susten- } \\
\text { tável }\end{array}$ & Total & $\begin{array}{l}\text { Prote- } \\
\text { ção } \\
\text { integral }\end{array}$ & $\begin{array}{l}\text { Uso } \\
\text { susten- } \\
\text { tável }\end{array}$ \\
\hline Total & 312 & 139 & 173 & 750457 & 361807 & 388649 & 8,8 & 4,2 & 4,6 \\
\hline Amazônia & 117 & 38 & 79 & 596959 & 295808 & 301151 & 14,2 & 7,1 & 7,2 \\
\hline Cerrado & 47 & 22 & 25 & 65739 & 46314 & 19425 & 3,2 & 2,3 & 1,0 \\
\hline Caatinga & 25 & 13 & 12 & 31824 & 4939 & 26885 & 3,8 & 0,6 & 3,2 \\
\hline Mata Atlântica & 93 & 52 & 41 & 36473 & 10973 & 25501 & 3,3 & 1,0 & 2,3 \\
\hline Pampa & 4 & 2 & 2 & 3672 & 475 & 3197 & 2,1 & 0,3 & 1,8 \\
\hline Pantanal & 2 & 2 & - & 1472 & 1472 & - & 1,0 & 1,0 & - \\
\hline \multicolumn{10}{|c|}{ Unidades de Conservação } \\
\hline Marinhas & 24 & 10 & 14 & 14317 & 1827 & 12490 & - & - & - \\
\hline
\end{tabular}

Fontes: 1. Indicadores de desenvolvimento sustentável: Brasil 2012. Rio de Janeiro: IBGE, 2012. Disponível em: <http://www. ibge.gov.br/home/geociencias/recursosnaturais/ids/default_2015.shtm>. Acesso em: jan. 2016. 2. Áreas protegidas. Cadastro Nacional de Unidades de Conservação - CNUC. Brasília, DF: Ministério do Meio Ambiente, Sistema Nacional de Unidades de Conservação - SNUC 2014. Disponível em: <http://www.mma.gov.br/areas-protegidas>. Acesso em: jan. 2016.

Notas: 1. Dados atualizados em 12.12.2012.

2. Exclusive as áreas das Unidades de Conservação marinhas.

3. As áreas de sobreposição entre as Unidades de Conservação foram consideradas na categoria de maior restrição.

4. Unidades de Conservação que abarcam limites entre biomas foram contabilizadas no bioma predominante.

5. Foram consideradas as áreas dos biomas disponibilizadas pelo IBGE (ÄREA..., 2012, Tab. 3926).

No Cerrado, o percentual de área destinada à proteção integral é de apenas 2,3\%, mas o conjunto de Unidades de Uso Sustentável tem área ainda inferior e não chega a 1\% do total do bioma. Na Caatinga, na Mata Atlântica e no Pampa, ao contrário, as Unidades de Conservação de Uso Sustentável ocupam um percentual de área muito superior ao das Unidades de Conservação de Proteção Integral, ainda que os números globais pudessem ser bem mais expressivos. A Caatinga, único bioma exclusivamente brasileiro com 25 Unidades de Conservação, o Pampa, com quatro, e o Pantanal, com duas (ambas de proteção integral), 
são os que têm menor número. Nos biomas marinhos, as Unidades de Conservação chegam a 24, das quais 14 de uso sustentável. De maneira geral, relatórios do Ministério do Meio Ambiente apontam o problema, ainda sem solução satisfatória, das populações que tradicionalmente extraíam recursos em áreas tornadas Unidades de Conservação de Proteção Integral.

\section{Leituras cadastrais da diversidade brasileira: indicadores de patrimônio natural e cultural}

É importante incluir, no conjunto das iniciativas em favor da preservação da diversidade biológica e cultural brasileira, os vários programas e convenções mundiais que, de forma direta ou indireta, protegem os bens naturais. Alguns programas se articulam com o modelo brasileiro, como as Reservas da Biosfera, da UNESCO, incluídas no texto do SNUC e cujas áreas-núcleo muitas vezes são também Unidades de Conservação do sistema nacional. De acordo com a proposta do programa Homem e Biosfera (Man and the Biosphere - MaB) da UNESCO, todos os biomas estão representados nas Reservas da Biosfera no Brasil, que incluem os Biomas Cerrado, Caatinga, Pantanal, além da Amazônia Central e da Mata Atlântica, inclusive o Cinturão Verde de São Paulo e a Serra do Espinhaço. Como mencionado anteriormente, a UnESCO conduz também as atividades ligadas ao Patrimônio Cultural Mundial, cuja lista inclui bens naturais.

No Brasil, o primeiro bem natural (Unidade de Conservação) a receber a honraria mundial de ser declarado de importância para a humanidade foi o Parque Nacional do Iguaçu, em 1986. O título se encontrava seriamente ameaçado, segundo o relatório de 2014 do Comitê do Patrimônio Mundial (WORLD HERITAGE COMMITTEE) ${ }^{7}$ devido à construção de uma pequena hidrelétrica rio acima e à abertura de uma antiga estrada incompatível com as finalidades do Parque Nacional e Patrimônio Mundial, que agora pode ser retirado da lista principal para ingressar na lista dos bens em perigo ou em necessidade de salvaguarda urgente.

Assim, há várias formas de avaliar a diversidade cultural resultante das condições particulares do Brasil, já descritas, a qual idealmente deve estar representada primeiramente nos bens do patrimônio cultural tombados e registrados em escalas municipal, estadual e nacional. O Brasil tem, além disso, os bens reconhecidos em escala global, ou seja, bens expressivos da riqueza cultural de toda a humanidade. Desde a realização da Convenção para a Proteção do Patrimônio Mundial, Cultural e Natural de 1972, um comitê recebe e avalia as candidaturas de bens propostas pelos órgãos nacionais de cultura para formar a Lista Representativa do Patrimônio Cultural Mundial (Quadro 4), que é divulgada pela UNESCO.

O patrimônio mundial do Brasil incluído na lista - até 2013 estavam inscritos 23 bens culturais materiais, naturais e imateriais - se distribui entre quase todos os biomas e Grandes Regiões do País, mas, por ser ainda pouco numeroso, não contempla totalmente a grande diversidade de interações com o meio, representadas pelas populações tradicionais.

\footnotetext{
7 Para informações mais detalhadas, consultar: CONVENTION Concerning the Protection of the World Cultural and Natural Heritage. In: WORLD HERITAGE COMMITTEE, 38., Doha, 15-25 June 2014. Paris: United Nations Organization for Education, Science and Culture - Unesco, 2014. p. 135. Disponível em: <http://whc.unesco.org/archive/2014/whc14-38com-7B-en.pdf>. Acesso em: jan. 2016.
} 
Existem, no entanto, muitas outras expressões de populações já aprovadas para a lista indicativa e à espera de compor a lista representativa do Patrimônio Cultural da Humanidade. A lista distingue, além dos bens imateriais representativos da herança cultural da humanidade, também os bens culturais e os bens naturais, ainda que, devido à reconhecida dificuldade de encaixar certos bens em uma ou outra categoria, tenha sido aceito o conceito de bens "mistos", descritos tanto como bens naturais quanto bens culturais. Mais recentemente, tem sido proposto o conceito de "paisagem cultural", exemplificado pela inclusão de mais um bem cultural do Brasil na lista mundial, em 2012: o Rio de Janeiro: paisagens cariocas entre a montanha e o mar.

Quadro 4 - Patrimônio Mundial no Brasil - 2013

\begin{tabular}{|c|c|}
\hline Lista representativa & Ano de inscrição \\
\hline \multicolumn{2}{|l|}{ Bens culturais } \\
\hline Rio de Janeiro: paisagens cariocas entre a montanha e o mar & 2012 \\
\hline Praça de São Francisco, São Cristóvão, Sergipe & 2010 \\
\hline Centro Histórico da Cidade de Goiás, Goiás & 2001 \\
\hline Centro Histórico de Diamantina, Minas Gerais & 1999 \\
\hline Centro Histórico de São Luís, Maranhão & 1997 \\
\hline Conjunto Urbanístico de Brasília, Distrito Federal & 1987 \\
\hline Centro Histórico de Salvador, Bahia & 1985 \\
\hline Santuário do Senhor Bom Jesus de Matosinhos, Congonhas, Minas Gerais & 1985 \\
\hline Ruínas de São Miguel das Missões, Rio Grande do Sul & 1983 \\
\hline Centro Histórico de Olinda, Pernambuco & 1982 \\
\hline Conjunto Arquitetônico e Urbanístico de Ouro Preto, Minas Gerais & 1980 \\
\hline \multicolumn{2}{|l|}{ Bens naturais } \\
\hline Ilhas Atlânticas: Parque Nacional de Fernando de Noronha e Atol das Rocas, Pernambuco & 2001 \\
\hline Áreas protegidas do Cerrado: Parque Nacional dos Veadeiros e das Emas, Goiás & 2001 \\
\hline Complexo de Áreas Protegidas do Pantanal, Mato Grosso e Mato Grosso do Sul & 2000 \\
\hline Complexo de Áreas Protegidas da Amazônia Central (Parque Nacional do Jaú), Amazonas & 2000 \\
\hline Mata Atlântica, Reservas do Sudeste, São Paulo e Paraná & 1999 \\
\hline Costa do Descobrimento, Bahia e Espírito Santo & 1999 \\
\hline Parque Nacional da Serra da Capivara, Piauí & 1991 \\
\hline Parque Nacional do Iguaçu, Paraná & 1986 \\
\hline \multicolumn{2}{|l|}{ Bens imateriais } \\
\hline Círio de Nazaré em Belém do Pará & 2013 \\
\hline Frevo do carnaval de Recife & 2012 \\
\hline Expressão oral e gráfica dos Wajãpi & 2008 \\
\hline Samba de Roda do Recôncavo Baiano & 2008 \\
\hline \multicolumn{2}{|l|}{ Bens com necessidade urgente de salvaguarda } \\
\hline Yaokwa, ritual do povo Enawene Nawe & 2011 \\
\hline \multicolumn{2}{|l|}{ Melhores práticas } \\
\hline Financiamento de Projetos de Patrimônio Imaterial & 2011 \\
\hline Museu Vivo do Fandango & 2011 \\
\hline
\end{tabular}

Fonte: Patrimônio mundial no Brasil. Brasília, DF: Organização das Nações Unidas para a Educação, a Ciência e a Cultura Unesco Brasil, [2015]. Disponível em: <http://www.unesco.org/new/pt/brasilia/culture/world-heritage/list-of-world-heritagein-brazil/\#c1048555>. Acesso em: jan. 2016. 
O patrimônio cultural brasileiro na lista da UNESCO reunia, em 2013, 11 bens culturais, oito bens naturais, quatro bens imateriais, além de um bem imaterial declarado em necessidade de salvaguarda urgente. Incluía ainda dois projetos criados no Brasil entre as melhores práticas do mundo de fomento ao Patrimônio Cultural Mundial. O Brasil tem implementado políticas inovadoras, inclusive novos instrumentos para a ação local, como o inventário e a premiada prática de incentivo a projetos locais de patrimônio imaterial. Paralelamente, esforços no campo da educação patrimonial também contribuem para consolidar os novos conceitos, que cada vez mais permitem a inclusão da ampla diversidade social brasileira no quadro econômico, social e cultural que compõe o Brasil.

A dificuldade de monitoramento da diversidade cultural é reconhecida mundialmente, mas pode se valer de indicadores como os que aparecem na edição de 2014 dos Indicadores de Desenvolvimento Sustentável, publicação do IBGE que há 12 anos, bianualmente, recolhe e atualiza avaliações das dimensões econômica, social, ambiental e institucional da sustentabilidade. Sob o título de Patrimônio Cultural, a dimensão institucional dos indicadores passou a incluir quadros, tabelas e mapas sobre o patrimônio cultural brasileiro tombado e registrado pelo IPHAN, além da lista de bens incluídos pela UNESCO na lista representativa do patrimônio mundial.

Já na década de 1930, muito antes da Convenção para a Proteção do Patrimônio Mundial, Cultural e Natural de 1972 e da adoção de listas pela comunidade internacional, o Brasil iniciou sua política de identificação e preservação do Patrimônio Cultural Material. Em 1938, foram feitas as primeiras inscrições de bens materiais nos livros do tombo, que, em 2012, já reuniam mais de mil bens culturais materiais históricos e artísticos, mas também arqueológicos, etnográficos, paisagísticos. A criação do órgão nacional de patrimônio cultural em 1937 marca o início oficial da política nacional para o tema, da qual participam como protagonistas também outras instituições, como o Centro Nacional de Folclore e Cultura Popular, criado em 1958, o Centro Nacional de Referência Cultural, na década de 1970, e depois a Fundação Nacional Pró-Memória, além dos órgãos estaduais e locais.

Esses órgãos governamentais realizaram vários projetos que antecipavam ideias mais tarde abarcadas pelo conceito de patrimônio imaterial, ampliando a atuação do Estado em relação ao patrimônio vinculado às culturas populares, às culturas indígenas e aos cultos afro-brasileiros. Essa orientação conduziu ao tombamento de dois importantes bens de matriz africana, já em 1986: a Serra da Barriga, em Alagoas, local do Quilombo dos Palmares, e o Terreiro da Casa Branca, em Salvador, um dos mais antigos e atuantes centros de atividade do candomblé baiano. Em 2000, foram tombados mais quatro terreiros em Salvador e um no Maranhão. Assim, no Livro do Tombo Arqueológico, Etnográfico e Paisagístico, bem como no Histórico, são feitas as primeiras inscrições de bens culturais associados a populações tradicionais de matriz africana, os quais depois encontrariam lugar também nos livros de registro de bens imateriais. 


\section{Quadro 5 - Alguns bens do Patrimônio Cultural Material do Brasil de matriz africana}

\begin{tabular}{|c|c|c|c|}
\hline $\begin{array}{c}\text { Bem material } \\
\text { (nome de inscrição oficial) }\end{array}$ & Localização & Livro(s) do Tombo & Data da inscrição \\
\hline $\begin{array}{l}\text { Serra da Barriga (Quilombo } \\
\text { dos Palmares; República dos Palmares) } \\
\text { (Serra da Barriga, } \\
\text { parte mais acantilada, conforme } \\
\text { descrição constante na } \\
\text { Informação no } 123 / 85 \text { ) }\end{array}$ & União dos Palmares (AL) & $\begin{array}{l}\text { Arqueológico/Etnográfico/ } \\
\text { Paisagístico e Histórico }\end{array}$ & 19.02.1986 \\
\hline $\begin{array}{l}\text { Terreiro da Casa Branca } \\
\text { (Terreiro da Casa Branca } \\
\text { constituído de uma área de } \\
\text { aproximadamente } 6.800 \mathrm{~m}^{2} \text {, } \\
\text { com as edificações, árvores e principais } \\
\text { objetos sagrados, } \\
\text { situado na Avenida Vasco } \\
\text { da Gama s/ } \mathrm{n}^{\circ} \text { ) }\end{array}$ & Salvador (BA) & $\begin{array}{l}\text { Arqueológico/Etnográfico/ } \\
\text { Paisagístico }\end{array}$ & 14.08 .1986 \\
\hline $\begin{array}{l}\text { Morro do Pai Inácio: conjunto } \\
\text { paisagístico e Rio Mucugêzinho } \\
\text { (Conjunto paisagístico do Morro } \\
\text { do Pai Inácio) }\end{array}$ & Palmeiras (BA) & $\begin{array}{l}\text { Arqueológico/Etnográfico/ } \\
\text { Paisagístico }\end{array}$ & 05.05 .2000 \\
\hline $\begin{array}{l}\text { Terreiro de Candomblé do } \\
\text { Axé Opô Afonjá (Terreiro } \\
\text { do Axé Opô Afonjá) }\end{array}$ & Salvador (BA) & $\begin{array}{l}\text { Arqueológico/Etnográfico/ } \\
\text { Paisagístico e Histórico }\end{array}$ & 28.07.2000 \\
\hline $\begin{array}{l}\text { Terreiro de Candomblé Ilê lyá } \\
\text { Omim Axé Yiamassé (Terreiro } \\
\text { do Gantois - Ilê lyá Omim Axé } \\
\text { Yiamassé) }\end{array}$ & Salvador (BA) & $\begin{array}{l}\text { Arqueológico/Etnográfico/ } \\
\text { Paisagístico e Histórico }\end{array}$ & 02.02 .2005 \\
\hline $\begin{array}{l}\text { Terreiro do Bate-Folha (Terreiro } \\
\text { de Candomblé do Bate-Folha } \\
\text { Manso Banduquenqué) }\end{array}$ & Salvador (BA) & $\begin{array}{l}\text { Arqueológico/Etnográfico/ } \\
\text { Paisagístico e Histórico }\end{array}$ & 03.02 .2005 \\
\hline $\begin{array}{l}\text { Terreiro de Alaketo, Ilê Maroiá Láji } \\
\text { (Terreiro do Alaketo, Ilê Maroiá Láji) }\end{array}$ & Salvador $(\mathrm{BA})$ & $\begin{array}{l}\text { Arqueológico/Etnográfico/ } \\
\text { Paisagístico e Histórico }\end{array}$ & 30.09 .2008 \\
\hline $\begin{array}{l}\text { Terreiro Casa das Minas Jeje (Terreiro } \\
\text { Casa das Minas Jeje, situado na Rua de } \\
\text { São Pantaleão n }{ }^{\circ} 857 \text { e } 857 a \text { ) }\end{array}$ & São Luís (MA) & $\begin{array}{l}\text { Arqueológico/Etnográfico/ } \\
\text { Paisagístico e Histórico }\end{array}$ & 02.02 .2005 \\
\hline $\begin{array}{l}\text { Quilombo do Ambrósio: documentação } \\
\text { (Documentação referente ao Quilombo } \\
\text { do Ambrósio) }\end{array}$ & Ibiá (MG) & Histórico & 11.07.2002 \\
\hline $\begin{array}{l}\text { Quilombo do Ambrósio: remanescentes } \\
\text { (Remanescentes do antigo Quilombo do } \\
\text { Ambrósio) }\end{array}$ & Ibiá (MG) & Histórico & 11.07.2002 \\
\hline
\end{tabular}

Fonte: Lista dos bens culturais inscritos nos livros do tombo (1938-2012). Rio de Janeiro: Instituto do Patrimônio Histórico Artístico Nacional - IPHAN, 2013. Disponível em: <http://portal.iphan.gov.br/uploads/ckfinder/arquivos/guia\%20de\%20bens\% 20tombados\%20atualizado\%20em\%202012.pdf>. Acesso em: jan. 2016. 
Da mesma natureza cultural que o patrimônio material, cujo tombamento, no entanto, depende da iniciativa do IPHAN, o registro de bens imateriais é realizado pelo órgão nacional de patrimônio cultural como resultado de um processo que surge da iniciativa das pessoas reunidas em associações e organizações da sociedade civil. Por esse motivo, muitas vezes tem servido como canal de fortalecimento da identidade de populações tradicionais e tende a crescer à medida que recebe incentivo no âmbito de programas oficiais ${ }^{8}$.

Por fim, é preciso acrescentar que, ao contrário do que possa sugerir, o livro de tombo que diz respeito aos bens paisagísticos não se restringe a paisagens de pura beleza cênica ou ligados a eventos históricos, como a chamada Costa do Descobrimento, onde, como se sabe, conjugam-se critérios ligados à importância cultural para o País, mas também de diversidade biológica excepcional. Os bens que figuram nas listas do patrimônio mundial do Brasil atendem aos mesmos critérios utilizados para decidir sobre a criação de uma nova unidade de conservação para o sistema nacional, entre elas a diversidade biológica e a existência de espécies endêmicas, ou seja, de ocorrência restrita àquela área. O tombamento também pode se oferecer como alternativa para a conservação de áreas naturais ocupadas por populações tradicionais.

O Mapa 7 mostra que os três estados onde, em 2012, se encontravam mais de 150 bens materiais inscritos nos quatro livros do tombo são Rio de Janeiro, Bahia e Minas Gerais. Com 51 a 150 bens materiais tombados, os Estados de São Paulo, Pernambuco e Rio Grande do Sul também têm um patrimônio material expressivo. Com relação à distribuição dos bens ao longo do tempo, a análise de sua quantidade em cada livro do tombo revela um crescimento proporcional dos tombamentos de bens arqueológicos, etnográficos e paisagísticos, em relação aos bens históricos e artísticos no período entre 1938 e 2012. No primeiro ano, houve grande quantidade de inscrições de bens de belas artes e históricos (respectivamente $67 \%$ e $32 \%$ do total de tombamentos), concentrados principalmente nas regiões Nordeste e Sudeste, como reflexo do próprio processo de povoamento do Brasil, inicialmente concentrado nessas áreas. Desde o ano 2000, no entanto, vem crescendo a proporção de bens inscritos no Livro do Tombo Arqueológico, Etnográfico e Paisagístico, os quais representavam 1\% do total em 1938, mas chegaram a 11\% em 2012, distribuídos principalmente pelas mesmas Regiões Nordeste e Sudeste, cada uma com 60 bens da categoria.

\footnotetext{
8 Outro canal de reconhecimento de direito coletivo de povos e comunidades tradicionais têm sido as chamadas Indicações Geográficas que, associadas a arranjos produtivos locais, podem ser registradas no Instituto Nacional de Propriedade Industrial - INPI, conforme a Lei da Propriedade Industrial n. 9.279, de 14.05.1996 em consonância com instrumentos internacionais da Organização Mundial do Comércio.
} 
Mapa 7 - Patrimônio Cultural Material do Brasil - 2012

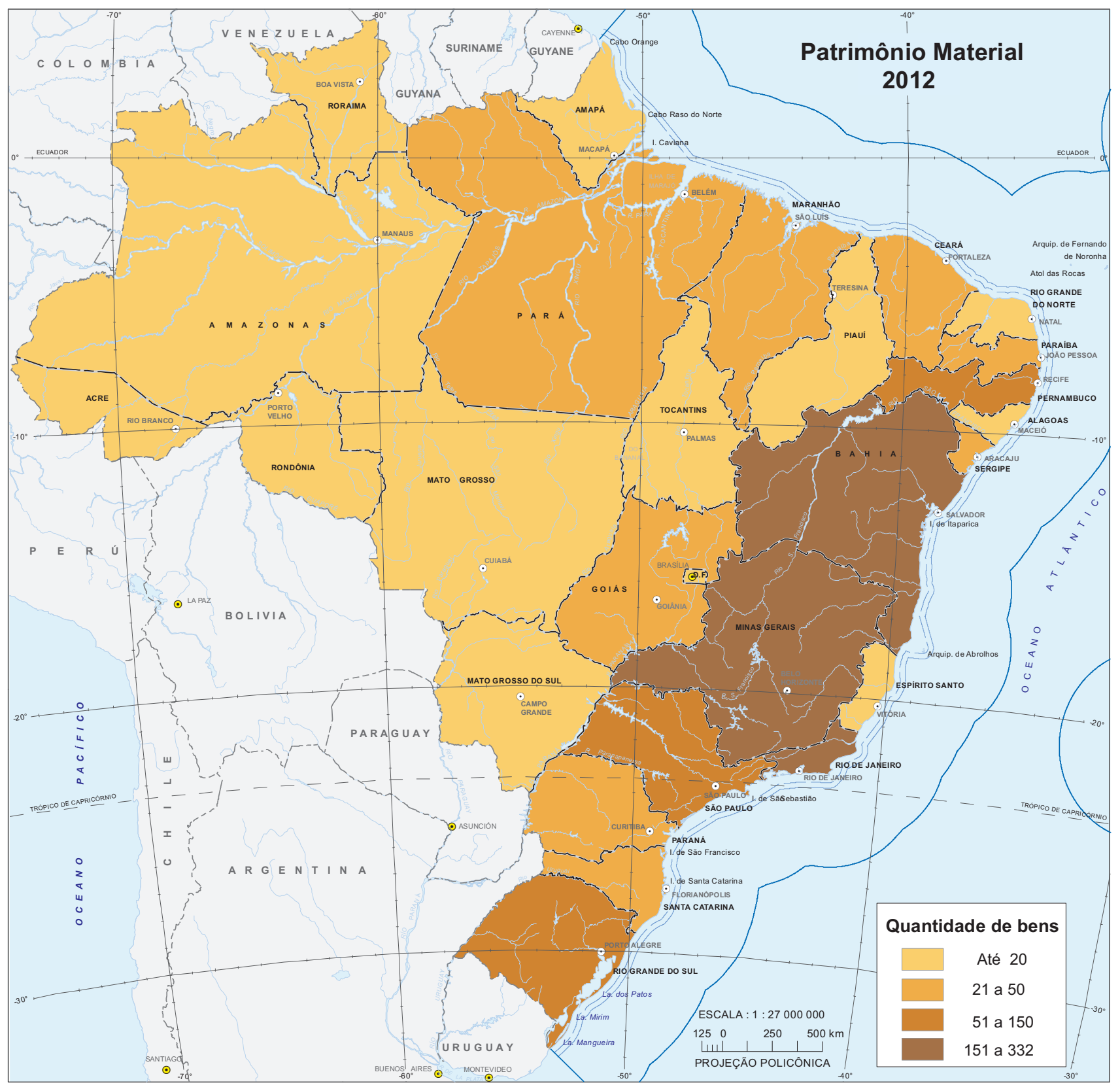

Fontes: 1. Lista dos bens culturais inscritos nos livros do tombo (1938 - 2012). Rio de Janeiro: Instituto do Patrimônio Histórico Artístico Nacional - IpHAN, 2013. Disponível em: <http://portal.iphan.gov.br/uploads/ckfinder/arquivos/guia $\% 20 \mathrm{de} \% 20$ bens $\% 20$ tombados $\% 20$ atualizado $\% 20$ em $\% 202012$.pdf >. Acesso em: jan. 2016. 2. Indicadores de desenvolvimento sustentável: Brasil 2015. Rio de Janeiro: IBGE, 2015. Disponível em: <http://www.ibge.gov.br/home/ geociencias/recursosnaturais/ids/default_2015.shtm>. Acesso em: jan. 2016. 


\section{Leituras cadastrais da diversidade brasileira: Indicadores de patrimônio imaterial}

Entre os bens do Patrimônio Imaterial do Brasil, em 2012, havia nove saberes, nove formas de expressão, seis celebrações e dois lugares. A inclusão, em 2013, de três celebrações e um saber, contribuiu para equilibrar o número de inscrições em três livros de registro. A inscrição de lugares foi criada para o registro de mercados, feiras, santuários, praças e demais espaços onde se concentram e se reproduzem práticas culturais coletivas, e pode, com seu crescimento, trazer maior contribuição para uma abordagem da diversidade cultural expressa em lugares que já incluem a cachoeira de lauaretê, lugar sagrado para indígenas de várias etnias do alto Rio Negro, na Amazônia, e a Feira de Caruaru, centro de divulgação de tradições nordestinas.

Quadro 6 - Patrimônio Imaterial - Brasil - 2002/2012

\begin{tabular}{|c|c|}
\hline Bens do Patrimônio Imaterial & $\begin{array}{c}\text { Ano de } \\
\text { inscrição }\end{array}$ \\
\hline \multicolumn{2}{|l|}{ Livro de Registro dos Saberes } \\
\hline Modo de fazer e práticas socioculturais associadas à cajuína & 2013 \\
\hline Saberes e Práticas Associados aos Modos de Fazer Bonecas Karajá & 2012 \\
\hline Sistema Agrícola Tradicional do Rio Negro & 2010 \\
\hline Modo de fazer Renda Irlandesa, tendo como referência este ofício em Divina Pastora (Sergipe) & 2009 \\
\hline Ofício de Sineiro & 2009 \\
\hline Modo artesanal de fazer Queijo de Minas, nas regiões do Serro e das serras da Canastra e do Salitre & 2008 \\
\hline Ofício dos Mestres de Capoeira & 2008 \\
\hline Modo de Fazer Viola-de-Cocho & 2005 \\
\hline Ofício das Baianas de Acarajé & 2005 \\
\hline Ofício das Paneleiras de Goiabeiras, Vitória (Espírito Santo) & 2002 \\
\hline \multicolumn{2}{|l|}{ Livro de Registro das Formas de Expressão } \\
\hline Rtixòkò: expressão artística e cosmológica do Povo Karajá & 2012 \\
\hline $\begin{array}{l}\text { Toque dos Sinos em Minas Gerais, tendo como referência São João del Rey e as cidades de Ouro Preto, Mariana, } \\
\text { Catas Altas, Congonhas, Diamantina, Sabará, Serro e Tiradentes }\end{array}$ & 2009 \\
\hline Roda de Capoeira & 2008 \\
\hline Frevo & 2007 \\
\hline Matrizes do Samba no Rio de Janeiro: Partido Alto, Samba de Terreiro e Samba-Enredo & 2007 \\
\hline Tambor de Crioula do Maranhão & 2007 \\
\hline Jongo no Sudeste & 2005 \\
\hline Samba de Roda do Recôncavo Baiano & 2004 \\
\hline Arte Kusiwa - Pintura Corporal e Arte Gráfica Wajãpi & 2002 \\
\hline \multicolumn{2}{|l|}{ Livro de Registro das Celebrações } \\
\hline Festa do Divino Espírito Santo de Paraty & 2013 \\
\hline Festa do Senhor Bom Jesus do Bonfim & 2013 \\
\hline São Sebastião na Região do Marajó & 2013 \\
\hline Fandango Caiçara & 2012 \\
\hline Complexo Cultural do Bumba-meu-boi do Maranhão & 2011 \\
\hline Festa de Sant' Ana de Caicó (Rio Grande do Norte) & 2010 \\
\hline Festa do Divino Espírito Santo de Pirenópolis (Goiás) & 2010 \\
\hline Ritual Yaokwa do povo indígena Enawene Nawe & 2010 \\
\hline Círio de Nossa Senhora de Nazaré & 2004 \\
\hline \multicolumn{2}{|l|}{ Livro de Registro dos Lugares } \\
\hline Cachoeira de lauaretê - Lugar sagrado dos povos indígenas dos Rios Uaupés e Papuri & 2006 \\
\hline Feira de Caruaru & 2006 \\
\hline
\end{tabular}

Fonte: Instituto do Patrimônio Histórico e Artístico Nacional - IPHAN. 
A partir da vinculação entre meio ambiente e cultura, é possível imaginar um indicador de diversidade cultural baseado na evolução da quantidade e da proporção de tombamentos de patrimônio material e registros de patrimônio imaterial, devendo, no entanto, necessariamente associá-los à sociodiversidade brasileira, possivelmente em articulação com a biodiversidade. Uma primeira abordagem mostra que, paralelamente à consolidação do pensamento socioambiental, nas três últimas décadas, ampliou-se no Brasil o leque de manifestações culturais representadas nos livros do tombo e de registro, e, consequentemente, também a visibilidade de vários segmentos da população que passaram a ter sua contribuição para a diversidade das expressões culturais no Brasil formalmente reconhecida.

O Fandango caiçara, por exemplo, se liga presumivelmente à população tradicional de mesmo nome, restrita ao litoral sul de São Paulo e norte do Paraná, mas nenhuma outra apresenta patrimônio imaterial mais numeroso, ainda que regionalmente restrito, que os povos indígenas. A compreensão da distribuição desses bens imateriais pode se apoiar na forte relação existente entre patrimônio cultural e populações tradicionais. Os povos poderão ser representados por seu patrimônio cultural quanto mais houver proximidade entre as instituições formais e os anseios de institucionalização da população organizada.

Remanescentes de antigos quilombos, as comunidades quilombolas estão encontrando seu caminho de reconhecimento e desenhando seu "mapa cultural", assim como já têm feito os indígenas que na atualidade habitam principalmente a parte ocidental do Brasil, delimitada pelos Estados do Pará, de Mato Grosso e de Mato Grosso do Sul, conforme o Mapa 8, justamente na região onde se encontrava, em 2012, a maior parte dos bens imateriais de origem indígena já incluídos nos quatro Livros de Registro do IPHAN: Livro de Registro dos Saberes; Livro de Registro das Celebrações; Livro de Registro das Formas de Expressão; e Livro de Registro dos Lugares ${ }^{9}$. Todos os livros de registro estão representados no conjunto do patrimônio imaterial indígena no Bioma Amazônia e áreas de transição com o Cerrado: o livro das celebrações registra o Ritual Yaokwa do Povo Indígena Enawene Nawe; o livro dos lugares registra a Cachoeira de lauaretê, lugar sagrado dos povos indígenas dos rios Uaupés e Papuri; o livro das formas de expressão inclui a Arte Kusiwa, que é a pintura corporal e arte gráfica dos Wajãpi; e o livro de saberes registra o Sistema Agrícola do Rio Negro. Dois outros bens imateriais se encontram no Bioma Cerrado - a expressão artística do povo Karajá, chamada Rtixòkò, registrada no livro das formas de expressão, e os saberes e práticas associados aos modos de fazer bonecas Karajá, no livro dos saberes.

\footnotetext{
9 Para informações mais detalhadas consultar o portal do IPHAN, no endereço: <http://portal.iphan.gov.br/pagina/detalhes/122>.
} 
Mapa 8 - Patrimônio Cultural Imaterial de origem indígena - 2012

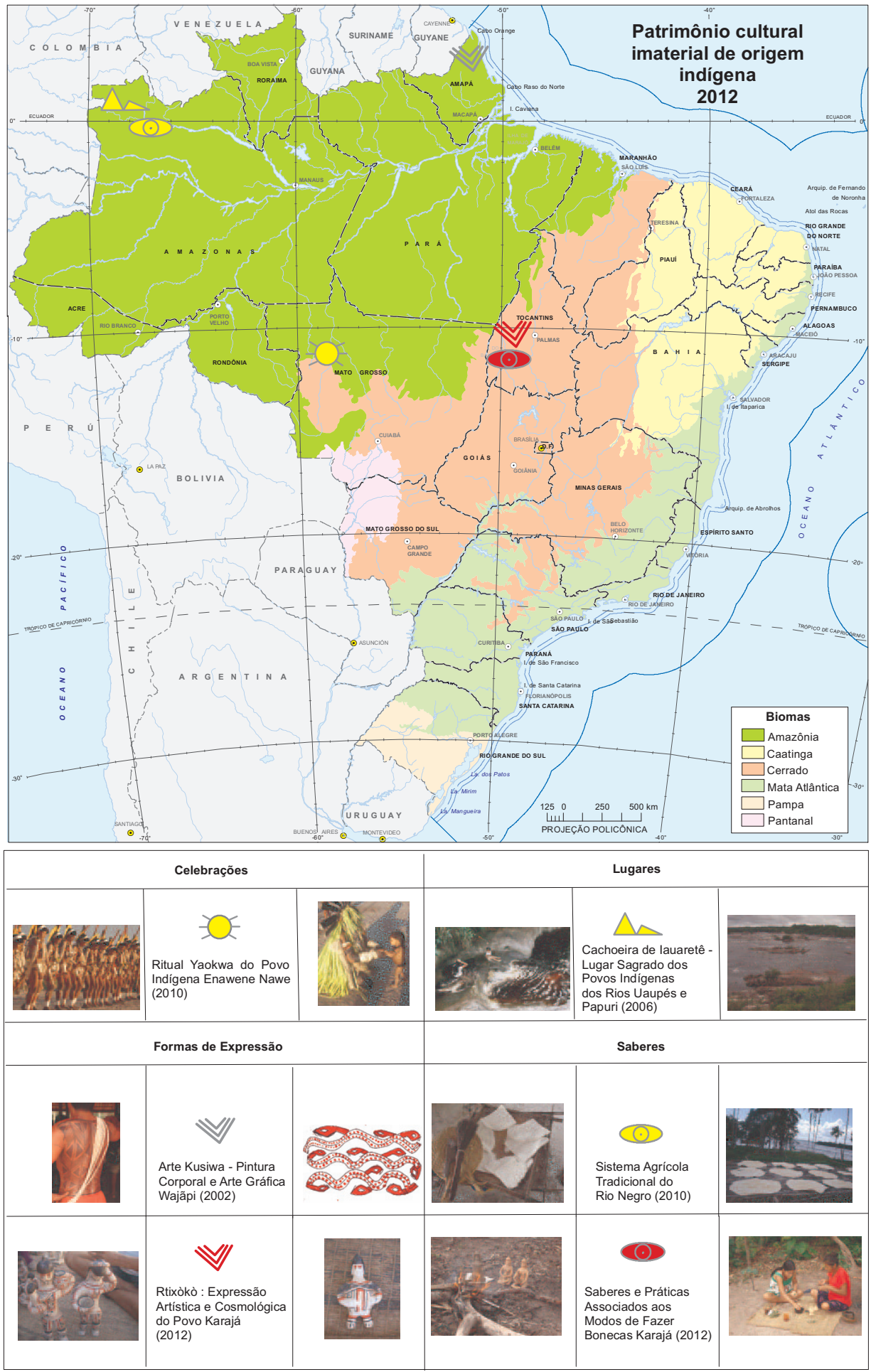

Fonte: Livros de registro. Rio de Janeiro: Instituto do Patrimônio Histórico e Artístico Nacional - IPHAN, 2016. Disponível em: <http://portal.iphan.gov.br/pagina/detalhes/122>. Acesso: jan. 2016.

Nota: Fotos: Acervo IPHAN. 
Em nível local, outros povos começam a promover sua identificação pelas expressões culturais, saberes e celebrações, além de lugares repletos de significados comuns, onde se renovam as tradições. À medida que se organizam e se fazem representar, outras populações podem enriquecer o indicador de patrimônio cultural, por meio da inscrição de novos bens materiais e imateriais. Quanto a um possível mapeamento da influência das culturas afro-brasileiras, a intensa miscigenação e o caldeirão cultural fazem com que alguns bens, de matriz africana, sejam considerados nacionais, como a capoeira, incluída com essa abrangência geográfica no Livro de Registro das Formas de Expressão, assim como o ofício do mestre de capoeira, incluído no Livro de Saberes do Patrimônio Imaterial do Brasil. A dimensão nacional da cultura das populações quilombolas também se revela na Constituição Federal de 1988, em seu Art. 216 (apresentado a seguir), item V, parágrafo 5, declara tombados "todos os documentos e os sítios detentores de reminiscências históricas dos antigos quilombos".

Atualmente, do Patrimônio Material do Brasil, quase metade (47\%) dos bens está inscrita no Livro do Tombo das Belas Artes, e 41\% são bens históricos. O Livro do Tombo de Artes Aplicadas contém apenas cinco inscrições em todo o Brasil (quatro bens na Região Nordeste e um no Sul). Em comparação com o ano de 1938, o número de bens de belas artes tombados triplicou até 2012, totalizando 697, enquanto os bens históricos mais que quintuplicaram, chegando a 606 em 2012. Os bens da categoria arqueológico, etnográfico e paisagístico aumentaram bem mais significativamente, passando de quatro bens tombados no primeiro ano para 159 até 2012.

Já contemplados no anteprojeto da política de preservação de bens culturais elaborado, a pedido do governo federal por Mário de Andrade, escritor modernista e também pesquisador da cultura brasileira, no início do Século XX, os bens imateriais só passaram a ser objeto de registro a partir da edição do Decreto n. 3.551, de 04.08.2000. Mundialmente, a Convenção para a Salvaguarda do Patrimônio Cultural, da UNESCO, reconheceu, em 2006, não ser a cultura dos povos constituída só de aspectos físicos, abrindo espaço também para as tradições, o folclore, os saberes, as línguas, as festas, transmitidos oral ou gestualmente, ou seja, a porção intangível da cultura dos povos.

Os bens imateriais expressam uma visão mais ampla de patrimônio cultural, formalizada, no Brasil, nos Arts. 215 e 216 da Constituição Federal de 1988, que trouxeram um grande avanço ao estabelecer a necessidade de elaboração de outras formas de acautelamento e preservação, além do tombamento, para saberes tradicionais, incluindo formas de expressão, modos de criar, fazer e viver, obras, objetos, documentos, edificações e demais espaços destinados às manifestações artístico-culturais; sítios de valor histórico, paisagístico, artístico, arqueológico, paleontológico, ecológico e científico. O trecho referido da Constituição Federal de 1988 inclui, no conceito de cultura, as manifestações populares indígenas e afro-brasileiras, bem como de outros grupos dos diferentes segmentos étnicos da população "participantes do processo civilizatório nacional", abrindo novas possibilidades de monitoramento e de proteção da diversidade por sua expressão no patrimônio cultural.

Art. 215. O Estado garantirá a todos o pleno exercício dos direitos culturais e acesso às fontes da cultura nacional, e apoiará e incentivará a valorização e a difusão das manifestações culturais. 
$\S 1^{\circ} \mathrm{O}$ Estado protegerá as manifestações das culturas populares, indígenas e afro-brasileiras, e das de outros grupos participantes do processo civilizatório nacional.

$\S 2^{\circ}$ A lei disporá sobre a fixação de datas comemorativas de alta significação para os diferentes segmentos étnicos nacionais.

$\S 3^{\circ}$ A lei estabelecerá o Plano Nacional de Cultura, de duração plurianual, visando ao desenvolvimento cultural do País e à integração das ações do poder público que conduzem à:

I - defesa e valorização do patrimônio cultural brasileiro;

II - produção, promoção e difusão de bens culturais;

III - formação de pessoal qualificado para a gestão da cultura em suas múltiplas dimensões;

IV - democratização do acesso aos bens de cultura;

$\checkmark$ - valorização da diversidade étnica e regional.

Art. 216. Constituem patrimônio cultural brasileiro os bens de natureza material e imaterial, tomados individualmente ou em conjunto, portadores de referência à identidade, à ação, à memória dos diferentes grupos formadores da sociedade brasileira, nos quais se incluem:

I - as formas de expressão;

II - os modos de criar, fazer e viver;

III - as criações científicas, artísticas e tecnológicas;

IV - as obras, objetos, documentos, edificações e demais espaços destinados às manifestações artístico-culturais;

$\mathrm{V}$ - os conjuntos urbanos e sítios de valor histórico, paisagístico, artístico, arqueológico, paleontológico, ecológico e científico.

$\S 1^{\circ} \mathrm{O}$ poder público, com a colaboração da comunidade, promoverá e protegerá o patrimônio cultural brasileiro, por meio de inventários, registros, vigilância, tombamento e desapropriação, e de outras formas de acautelamento e preservação.

$\S 2{ }^{\circ}$ Cabem à administração pública, na forma da lei, a gestão da documentação governamental e as providências para franquear sua consulta a quantos dela necessitem.

$\S 3^{\circ} \mathrm{A}$ lei estabelecerá incentivos para a produção e o conhecimento de bens e valores culturais.

$\S 4^{\circ}$ Os danos e ameaças ao patrimônio cultural serão punidos, na forma da lei.

$\S 5^{\circ}$ Ficam tombados todos os documentos e os sítios detentores de reminiscências históricas dos antigos quilombos.

$\S 6^{\circ}$ É facultado aos Estados e ao Distrito Federal vincular a fundo estadual de fomento à cultura até cinco décimos por cento de sua receita tributária líquida, para o financiamento de programas e projetos culturais, vedada a aplicação desses recursos no pagamento de:

I - despesas com pessoal e encargos sociais;

II - serviço da dívida;

III - qualquer outra despesa corrente não vinculada diretamente aos investimentos ou ações apoiados. (BRASIL, 2009).

Assim como o Patrimônio Cultural Material informa sobre o povoamento e a colonização do Brasil, o Patrimônio Imaterial pode ser interpretado como o lugar natural de visibilidade das populações tradicionais, ainda que em alguns casos se tenha optado pelo tombamento 
como bens históricos; e arqueológicos, etnográficos e paisagísticos, como ocorreu com os bens de matriz africana entre 1986 e 2002. Os povos indígenas, por exemplo, em 2003, tiveram reconhecida a pintura corporal e arte gráfica Wajãpi, incluída primeiramente no Patrimônio Cultural Imaterial brasileiro. Sua visibilidade se ampliou quando esta forma de expressão foi declarada obra-prima da humanidade e, mais tarde, incluída na lista representativa do patrimônio mundial imaterial.

Quadro 7 - Patrimônio Imaterial, segundo os livros de registro de populações indígenas - Brasil - 2002/2012

\begin{tabular}{|l|c|}
\hline \multicolumn{1}{|c|}{ Patrimônio Imaterial } & Ano de inscrição \\
\hline \multicolumn{1}{|c|}{ Livro de Registro dos Saberes } & 2010 \\
$\begin{array}{l}\text { Sistema Agrícola Tradicional do Rio Negro } \\
\text { Saberes e Práticas Associados aos Modos de Fazer Bonecas Karajá }\end{array}$ & 2012 \\
\hline$\quad$ Livro de Registro das Formas de Expressão & 2002 \\
Arte Kusiwa - Pintura Corporal e Arte Gráfica Wajãpi & 2012 \\
Rtixòkò: expressão artística e cosmológica do Povo Karajá & 2010 \\
\hline$\quad$ Livro de Registro das Celebrações & 2006 \\
Ritual Yaokwa do povo indígena Enawene Nawe & \\
\hline Livro de Registro dos Lugares & \\
\hline Cachoeira de lauaretê - Lugar sagrado dos povos indígenas dos Rios Uaupés e Papuri & \\
\hline
\end{tabular}

Fonte: Instituto do Patrimônio Histórico Artístico Nacional - IPHAN.

Outros bens imateriais indígenas constituem sistemas profundamente enraizados na relação dessas populações com a natureza, mas em 2010, pela primeira vez, foi feito o registro de um sistema propriamente dito no Livro de Registro dos Saberes. O sistema agrícola tradicional do Rio Negro envolve cultura material, parentesco, rituais e celebrações, resultando em agrobioversidade, outra modalidade de diversidade que precisa encontrar seu caminho de preservação, diante da grave erosão genética causada pela homogeneização das espécies cultivadas (CUNHA, 2012).

Também o registro de dois bens distintos relacionados com os povos Karajá, do Brasil Central, em 2012, permitiu consagrar não apenas como conhecimentos os saberes e as práticas relacionadas ao modo de fazer bonecas Karajá, mas também incluiu no Livro de Registro das Formas de Expressão o próprio Rtixòkò: expressão artística e cosmológica dos Karajá, pois, em conjunto, esses bens constituem uma forma pela qual as crianças, novos membros da comunidade, aprendem o que é ser Karajá. As bonecas Karajá se integram ao cotidiano das populações indígenas das margens do Rio Araguaia e da Ilha do Bananal, confeccionadas a partir de conhecimentos tradicionais e recursos locais - como a argila, extraída de barreiros formados na vazante dos rios, e a tintura extraída do urucum, entre outras plantas envolvidas no processo, inclusive na produção das cinzas que se misturam à argila. 
A noção de patrimônio material e imaterial precisou ser diferenciada, como foi dito, mas não diferem verdadeiramente suas características de identificação, registro e conservação de bens em razão de sua representatividade e relação com identidades culturais nas respectivas escalas geográficas. Do mesmo modo, o patrimônio ambiental vem encontrando vários caminhos para aliar a conservação da diversidade biológica e cultural. Espera-se que a noção de sistema continue a orientar os encaminhamentos, tendo em vista o que preconiza o Plano Nacional de Cultura - PNC, instituído na Lei n. 12.343, de 02.12.2010, onde se recomenda a valorização da diversidade cultural e da cultura como vetor de desenvolvimento sustentável de um país cuja dimensão territorial e populacional contribui significativamente para torná-lo mais diverso e rico em termos de seu patrimônio cultural e natural da humanidade.

\section{Referências}

ALIMENTO: direito sagrado. Pesquisa Socioeconômica e Cultural de Povos e Comunidades Tradicionais de Terreiros. Brasília, DF: Ministério do Desenvolvimento Social e Combate à Fome, 2011. 200 p. Disponível em: <http://www.ideiasnamesa.unb.br/upload/bibliotecaldeias/ 04112015130257ok_Alimento_Direito_Sagrado_web.pdf>. Acesso em: jan. 2016.

ALTAFIN, I., VILAR, I. Novo Código Florestal mantém percentuais de reserva legal, mas isenta parte dos produtores da recomposição. Senado notícias, Brasília, DF: Senado Federal, 2011. Disponível em: <http://www12.senado.gov.br/noticias/materias/2011/12/07/novocodigo-florestal-mantem-percentuais-de-reserva-legal-mas-isenta-parte-dos-produtores-darecomposicao>. Acesso em: jan. 2016.

ANDRADE, M. de. Anteprojeto para a criação do Serviço do Patrimônio Artístico Nacional. Revista do Patrimônio Histórico e Artístico Nacional, Brasília, DF: IPHAN, n. 30, p. 270-287, 2002. Disponível em: <http://docvirt.no-ip.com/docreader.net/DocReader.aspx?bib=reviphan \&pagfis=10933\&pesq=>. Acesso em: jan. 2016 .

ÁREA dos biomas. In: IBGE. Sidra: sistema IBGE de recuperação automática. Rio de Janeiro, [2012]. IPCA dessazonalizado. tab. 3926. Disponível em: <http://www.sidra.ibge.gov.br/ bda/>. Acesso em: dez. 2012.

ÁREAS protegidas. Brasília, DF: Ministério do Meio Ambiente, Sistema Nacional de Unidades de Conservação - SNUC 2014. Disponível em: <http://www.mma.gov.br/areas-protegidas>. Acesso em: jan. 2016.

ÁREAS protegidas. Cadastro Nacional de Unidades de Conservação - CNUC. Brasília, DF: Ministério do Meio Ambiente, Sistema Nacional de Unidades de Conservação - SNUC 2014. Disponível em: <http://www.mma.gov.br/areas-protegidas>. Acesso em: jan. 2016.

BRASIL. Constituição (1988). Constituição da República Federativa do Brasil. Brasília, DF, [2009]. Disponível em: <http://www.presidencia.gov.br/legislacao> Acesso em: jan. 2016.

. Decreto n. 4.887, de 20 de novembro de 2003. Regulamenta o procedimento para identificação, reconhecimento, delimitação, demarcação e titulação das terras ocupadas por remanescentes das comunidades dos quilombos de que trata o art. 68 do Ato das 
Disposições Constitucionais Transitórias. Diário Oficial da União, Brasília, DF, ano 140, n. 227, 21. nov. 2003. Seção 1, p. 4-5. Disponível em: <http://www.presidencia.gov.br/ legislacao>. Acesso em: jan. 2016.

Decreto n. 6.040, de 7 de fevereiro de 2007. Institui a Política Nacional de Desenvolvimento Sustentável dos Povos e Comunidades Tradicionais. Diário Oficial da União, Brasília, DF, ano 144, n. 28, 8 fev. 2007a. Seção 1, p. 316-317. Disponível em: $<$ http://www.presidencia.gov.br/legislacao >. Acesso em: jan. 2016.

Lei n. 9.985, de 18 de julho de 2000. Regulamenta o artigo 225, parágrafo 1, incisos I, II, III e VII da Constituição Federal, institui o Sistema Nacional de Unidades de Conservação da Natureza e dá outras providências. Diário Oficial [da] República Federativa do Brasil, Brasília, DF, 19 jul. 2000. p. 1, c. 1. Disponível em: <http://www.presidencia.gov. br/legislacao $>$. Acesso em: jan. 2016.

Lei n. 12.343, de 2 de dezembro de 2010. Institui o Plano Nacional de Cultura PNC, cria o Sistema Nacional de Informações e Indicadores Culturais - SNIIC e dá outras providências. Diário Oficial da União, Poder Legislativo, Brasília, DF, ano 142, n. 231, 3 dez. 2010a. Seção 1, p. 1. Disponível em: <http://www.presidencia.gov.br/legislacao>. Acesso em: jan. 2016.

Ministério do Desenvolvimento Social e Combate à Fome. Guia de cadastramento de grupos populacionais tradicionais e específicos. Brasília, DF, 2012. Disponível em: <http:// mds.gov.br/assuntos/cadastro-unico/a-gestao-do-cadastro/processo-de-cadastramento/ cadastramento-diferenciado>. Acesso em: jan. 2016.

CENSO AGROPECUÁRIO 2006. Agricultura familiar: primeiros resultados. Brasil, grandes regiões e unidades da federação. Rio de Janeiro: IBGE, 2009. Disponível em: <http://www. ibge.gov.br/home/estatistica/economia/agropecuaria/censoagro/agri_familiar_2006_2/ apresentacao.shtm>. Acesso em: jan. 2016.

CENSO DEMOGRÁFICO 2010. Características da população e dos domicílios: resultados do universo. Rio de Janeiro: IBGE, 2011. Disponível em: <http://www.ibge.gov.br/home/ estatistica/populacao/censo2010/caracteristicas_da_populacao/default_caracteristicas_da_ populacao.shtm >. Acesso em: jan. 2016.

CONVENTION Concerning the Protection of the World Cultural and Natural Heritage. In: WORLD HERITAGE COMMITTEE, 38., Doha, 15-25 June 2014. Paris: United Nations Organization for Education, Science and Culture - Unesco, 2014. p. 135. Disponível em: <http://whc.unesco.org/archive/2014/whc14-38com-7B-en.pdf>. Acesso em: jan. 2016.

CUNHA, M. C. da. Questões suscitadas pelo conhecimento tradicional. Revista de Antropologia, São Paulo: Universidade de São Paulo - USP, v. 55, n. 1, p. 439-464, 06 nov. 2012. Disponível em: <http://www.revistas.usp.br/ra/article/view/46971/51311>. Acesso em: jan. 2016.

DECLARAÇÃO universal sobre a diversidade cultural. Brasília, DF: United Nations Organization for Education, Science and Culture - Unesco, 2002. Artigo 1. Disponível em: <http://unesdoc.unesco.org/images/0012/001271/127160por.pdf>. Acesso em: jan. 2016. 
DIEGUES, A. C. O mito moderno da natureza intocada. São Paulo: Hucitec, 1996. (Geografia: teoria e realidade; 35 ).

FLORESTAS tropicais, mitigação e adaptação às mudanças climáticas. Brasília, DF: Ministério do Meio Ambiente, Secretaria de Mudanças Climáticas e Qualidade Ambiental, abr. 2012. (Nota informativa n. 1). Disponível em: <http://www.mma.gov.br/redd/images/Publicacoes/ mma_notainformativa_01.pdf>. Acesso em: jan. 2016.

FREIRE, J. R. B. Rio Babel: a história das línguas na Amazônia. Rio de Janeiro: Ed. Uerj; Atlântica, 2004. (Coleção Brasilis).

GIESBRECHT, H. O.; SCHWANKE, F. H.; MÜSSNICH, A. G. Indicações geográficas Brasileiras. Brasília, DF: Serviço Brasileiro de Apoio às Micro e Pequenas Empresas - Sebrae: Instituto Nacional da Propriedade Intelectual - INPI, 2011.

INDICADORES de desenvolvimento sustentável: Brasil 2012. Rio de Janeiro: IBGE, 2012. Disponível em: <http://www.ibge.gov.br/home/geociencias/recursosnaturais/ids/ default_2015.shtm>. Acesso em: jan. 2016.

INDICADORES de desenvolvimento sustentável: Brasil 2015. Rio de Janeiro: IBGE, 2015. Disponível em: <http://www.ibge.gov.br/home/geociencias/recursosnaturais/ids/ default_2015.shtm>. Acesso em: jan. 2016.

LÉVI-STRAUSS, C. Raça e cultura. In: Raça e história. Lisboa: Presença, 1973. (Universidade hoje, 14). p. 66. Disponível em: <http://charlezine.com.br/wp-content/ uploads/Ra\%C3\%A7a-e-Hist\%C3\%B3ria-L\%C3\%A9vi-Strauss.pdf>. Acesso em: jan. 2016..

LISTA dos bens culturais inscritos nos livros do tombo (1938 - 2012). Rio de Janeiro: Instituto do Patrimônio Histórico Artístico Nacional - IPHAN, 2013. 157 p. Disponível em: <http://portal. iphan.gov.br/uploads/ckfinder/arquivos/guia\%20de\%20bens\%20tombados\%20atualizado\%20 em\%202012.pdf>. Acesso em: jan. 2016.

LIVROS de registro. Rio de Janeiro: Instituto do Patrimônio Histórico e Artístico Nacional - IPHAN, 2016. Disponível em: <http://portal.iphan.gov.br/pagina/detalhes/122>. Acesso: jan. 2016.

MACHADO, A. B. M.; DRUMMOND, G. M.; PAGLIA, A. P. (Ed.). Livro vermelho da fauna brasileira ameaçada de extinção. Brasília, DF: Ministério do Meio Ambiente, 2008. 2 v. (Biodiversiadede, 19). Disponível em: <http://www.mma.gov.br/publicacoes/biodiversidade/ category/55-especies-ameacadas-de-extincao >. Acesso em: jan. 2016.

MACHADO, A. B. M.; DRUMMOND, G. M.; PAGLIA, A. P. A fauna brasileira ameaçada de extinção: síntese taxonômica e geográfica. In: . (Ed.). Livro vermelho da fauna brasileira ameaçada de extinção. Brasília, DF: Ministério do Meio Ambiente; Belo Horizonte: Fundação Biodiversitas, 2008. (Biodiversidade, 19). V. 1. p. 63. Disponível em: <http://www. mma.gov.br/publicacoes/biodiversidade/category/55-especies-ameacadas-de-extincao $>$. Acesso em: jan. 2016. 
MAPA de biomas do Brasil. Rio de Janeiro: IBGE, 2004a. 1 mapa, color. Escala 1: 5.000.000; proj. policônica. Disponível em: <ftp://ftp.ibge.gov.br/Cartas_e_Mapas/Mapas_Murais/>. Acesso em: jan. 2016.

MAPA de vegetação do Brasil. Rio de Janeiro: IBGE, 2004b. 1 mapa, color. Escala 1:5 000 000. Projeção policônica. Disponível em: <ftp://ftp.ibge.gov.br/Cartas_e_Mapas/ Mapas_Murais/>. Acesso em: jan. 2016.

MEGADIVERSIDADE. Belo Horizonte: Conservação Internacional - Cl Brasil, v. 1-5, 20052009. Disponível em: <http://www.conservation.org/global/brasil/publicacoes/Pages/ revista-megadiversidade.aspx>. Acesso em: jan. 2016.

MORAES, A. C. R. Geografia: pequena história crítica. 13. ed. São Paulo: Hucitec, 1994. $138 \mathrm{p.}$

OLIVEIRA, L. Composição vegetal dos biomas continentais brasileiros, 2004. Quadro apresentado no material didático da disciplina "Vegetação e Biomas Brasileiros", ministrada no curso de Especialização em Análise Ambiental e Gestão do Território da Escola Nacional de Ciências Estatísticas - ENCE em 2004.

PÁDUA, J. A. Natureza e projeto nacional: as origens da ecologia política no Brasil. In: . Ecologia e política no Brasil. 2. ed. Rio de Janeiro: Espaço e Tempo: Instituto Universitário de Pesquisas do Rio de Janieor - IUPERJ, 1987.

PATRIMÔNIO mundial no Brasil. Brasília, DF: Organização das Nações Unidas para a Educação, a Ciência e a Cultura - Unesco Brasil, [2015]. Disponível em: <http://www.unesco. org/new/pt/brasilia/culture/world-heritage/list-of-world-heritage-in-brazil/\#c1048555>. Acesso em: jan. 2016.

PESQUISA Socioeconômica e Cultural de Povos e Comunidades Tradicionais de Terreiros: síntese de Resultados. In: ALIMENTO: direito sagrado. Pesquisa Socioeconômica e Cultural de Povos e Comunidades Tradicionais de Terreiros. Brasília, DF: Ministério do Desenvolvimento Social e Combate à Fome, 2011. p. 138. Disponível em: <http://www.ideiasnamesa.unb. br/upload/bibliotecaldeias/04112015130257ok_Alimento_Direito_Sagrado_web.pdf>. Acesso em: jan. 2016.

POVOS do cerrado. Brasília, DF: Pesquisa e Conservação do Cerrado - PEQUI, [2006]. Disponível em: <http://www.pequi.org.br/povos.html>. Acesso em: jan. 2016.

RESERVA da biosfera. In: ÁREAS protegidas. Ações e iniciativas. Gestão territorial para a conservação. Brasília, DF: Ministério do Meio Ambiente, 2014. Disponível em: <http:// www.mma.gov.br/areas-protegidas>. Acesso em: jan. 2016.

RIBEIRO, D. O povo brasileiro: a formação e o sentido do Brasil. São Paulo: Companhia das Letras, 1995. $470 \mathrm{p}$.

ROCHE, J. A colonização alemã no Espírito Santo. São Paulo: Difusão Europeia do Livro: EdUSP, 1968. 367 p. (Corpo e Alma do Brasil, 28.).

SAMPAIO, T. O tupi na geografia nacional. 2. ed. São Paulo: Pensamento, 1914. 
SANTILLI, J. Socioambientalismo e novos direitos: proteção jurídica à diversidade biológica e cultural. São Paulo: Peirópolis: Instituto Socioambiental; Brasília, DF: Instituto Internacional de Educação do Brasil, 2005. 303 p. Originalmente apresentada como dissertação de Mestrado na Universidade de Brasília - UnB, Brasília, DF, 2004.

SANTILLI, J. Agrobiodiversidade e direitos dos agricultores. São Paulo: Peirópolis, 2009. 519 p. SHIRAISHI NETO, J. (Org.). Direito dos povos e das comunidades tradicionais no Brasil: declarações, convenções internacionais e dispositivos jurídicos definidores de uma política nacional. Manaus: Universidade Federal do Amazonas - UFAM, Programa de PósGraduação em Sociedade e Cultura na Amazônia - PPGSCA; Fundação Ford, 2007. 230 p. (Coleção documentos de bolso, n. 1). Disponível em: <http://novacartografiasocial.com/? wpdmact=process\&did=MjEuaG90bGluaw==>. Acesso em: jan. 2016.

SILVA, J. A. da. Direito ambiental constitucional. São Paulo: Malheiros, 2007. 6. ed.

UNIDADES de conservação. Brasília, DF: Ministério do Meio Ambiente, Instituto Chico Mendes de Conservação da Biodiversidade - ICMBio, 2014. Disponível em: <http://www. icmbio.gov.br/portal/biodiversidade/unidades-de-conservacao/biomas-brasileiros.html>. Acesso em: jan. 2016.

WAINER, A. H. Legislação ambiental brasileira, subsídios para a história do direito ambiental. 2. ed. Rio de Janeiro: Forense, 1999.

WANDSCHEER, C. B. Integração e proteção das comunidades de remanescentes de quilombos com base nos princípios e normas constitucionais brasileiras: uma questão de justiça social. In: LIBERATO, A. P. Direito socioambiental em debate. Curitiba: Juruá, 2006. p. 37-68. 